\title{
Article \\ Curcuminoid Co-Loading Platinum Heparin-Poloxamer P403 Nanogel Increasing Effectiveness in Antitumor Activity
}

Ngoc The Nguyen ${ }^{1, *}$, Quynh Anh Bui ${ }^{2} \oplus$, Hoang Huong Nhu Nguyen ${ }^{3}$, Tien Thanh Nguyen ${ }^{1}$, Khanh Linh Ly ${ }^{1}$,

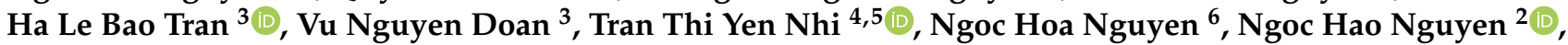
Ngoc Quyen Tran ${ }^{2,4}$ and Dinh Trung Nguyen ${ }^{2, *}$ (C)

check for updates

Citation: Nguyen, N.T.; Bui, Q.A.; Nguyen, H.H.N.; Nguyen, T.T.; Ly, K.L.; Tran, H.L.B.; Doan, V.N.; Nhi, T.T.Y.; Nguyen, N.H.; Nguyen, N.H.; et al. Curcuminoid Co-Loading Platinum Heparin-Poloxamer P403 Nanogel Increasing Effectiveness in Antitumor Activity. Gels 2022, 8, 59 . https://doi.org/10.3390/ gels8010059

Academic Editor: Weimin Li

Received: 23 November 2021

Accepted: 10 January 2022

Published: 14 January 2022

Publisher's Note: MDPI stays neutral with regard to jurisdictional claims in published maps and institutional affiliations.

Copyright: (C) 2022 by the authors. Licensee MDPI, Basel, Switzerland. This article is an open access article distributed under the terms and conditions of the Creative Commons Attribution (CC BY) license (https:// creativecommons.org/licenses/by/ $4.0 /)$.
1 Faculty of Medicine-Pharmacy, Tra Vinh University, Tra Vinh City 87000, Vietnam; nguyentienthanh@tvu.edu.vn (T.T.N.); lykhanhlinh@tvu.edu.vn (K.L.L.)

2 Institute of Applied Materials Science, Vietnam Academy of Science and Technology, Ho Chi Minh City 71500, Vietnam; quynhanhbui011@gmail.com (Q.A.B.); haonguyen101297@gmail.com (N.H.N.); tnquyen979@gmail.com (N.Q.T.)

3 Faculty of Biology and Biotechnology, University of Science-Vietnam National University, Ho Chi Minh City 72700, Vietnam; huongnhu2608@gmail.com (H.H.N.N.); tlbha@hcmus.edu.vn (H.L.B.T.); dnvu@hcmus.edu.vn (V.N.D.)

4 Graduate University of Science and Technology, Vietnam Academy of Science and Technology, Ho Chi Minh City 71500, Vietnam; ttynhi@ntt.edu.vn

5 Institute of Environmental Technology and Sustainable Development, Nguyen Tat Thanh University, Ho Chi Minh City 72800, Vietnam

6 German Vietnamese Technology Center, HCMC University of Food Industry, Ho Chi Minh City 72000, Vietnam; hoann@hufi.edu.vn

* Correspondence: nnt.the@gmail.com (N.T.N.); trungnd.iams@gmail.com (D.T.N.); Tel.: +84-939417019 (N.T.N.); +84-563293055 (D.T.N.)

\begin{abstract}
Nanosized multi-drug delivery systems provide synergistic effects between drugs and bioactive compounds, resulting in increased overall efficiency and restricted side effects compared to conventional single-drug chemotherapy. In this study, we develop an amphiphilic heparin-poloxamer P403 (HP403) nanogel that could effectively co-load curcuminoid (Cur) and cisplatin hydrate (CisOH) (HP403@CisOH@Cur) via two loading mechanisms. The HP403 nanogels and HP403@CisOH@Cur nanogels were closely analyzed with ${ }^{1} \mathrm{H}-\mathrm{NMR}$ spectroscopy, FT-IR spectroscopy, TEM, and DLS, exhibiting high stability in spherical forms. In drug release profiles, accelerated behavior of Cur and $\mathrm{CisOH}$ at $\mathrm{pH} 5.5$ compared with neutral $\mathrm{pH}$ was observed, suggesting effective delivery of the compounds in tumor sites. In vitro studies showed high antitumor activity of HP403@CisOH@Cur nanogels, while in vivo assays showed that the dual-drug platform prolonged the survival time of mice and prevented tail necrosis. In summary, HP403@CisOH@Cur offers an intriguing strategy to achieve the cisplatin and curcumin synergistic effect in a well-designed delivery platform that increases antitumor effectiveness and overcomes undesired consequences caused by cisplatin in breast cancer treatment.
\end{abstract}

Keywords: poloxamer P403; multi-drug delivery; heparin; MCF-7; nanogel

\section{Introduction}

Cisplatin (Cis-diamminedichloroplatinum (II)) is a standard first-line treatment for human breast cancer [1-6]. It is one of the prime anticancer drugs for many types of solid tumors and the first platinum compound approved by the FDA for treating testicular and ovarian cancer since 1978 [3-6]. However, the toxicity of cisplatin has caused many side effects on the kidney, marrow failure, chronic neurotoxicity, etc., leading to drug resistance and limiting dosage during treatment. Moreover, the poor selectivity between normal and tumor tissue has hindered cisplatin's prospect in clinical fields [6,7]. Several approaches have been developed to improve the therapeutic efficiency of cisplatin and overcome 
its limitations, such as novel platinum drugs, nanosized delivery systems, combination therapy treatment with other anticancer drugs, or phytochemical compounds (polyphenols, flavonoid, etc.) $[2,4,6,7]$. Among the regimens, therapeutic formulations of cisplatin and phytocompounds proved synergistic effects in cancer treatment and reduction of drug side effects, contributing to the expansion of its clinical usage [8-10].

Curcumin (Cur), a polyphenol derivative that originated in turmeric rhizome (Curcuma longa L.), has been shown to prevent skin cancer, stomach cancer, and bowel cancer in mice [11-17]. Besides having broad biological activity and excellent pharmacokinetics, curcumin is also non-toxic to small and large animals, even at high concentrations [18-21]. More interestingly, recent reports have revealed that Cur can create a synergistic effect with Cis, enhance tumor-proliferative inhibition and control side effects caused by monocisplatin regimens [8-10,22-26].

However, Cis and Cus are both hydrophobic compounds and have poor oral bioavailability $[2,11]$. In this study, we have attempted to load Cis and Cur into amphiphilic drug nano-carriers. Ideally, such nanosystems allow specific drug targeting, improving efficacy, and minimizing systematic toxicity $[27,28]$. One candidate of interest is poloxamer, a group of amphiphilic and biocompatible polymers [29]. Poloxamer has the symmetric triblock copolymer structure PEO-PPO-PEO, consisting of hydrophilic PEO regions (poly (ethylene oxide)) and hydrophobic PPO regions (poly (propylene oxide)) [30,31]. The hydrophobic cores containing water-insoluble drugs are surrounded by the hydrophilic shell, thus increasing the solubility and permeability of loaded compounds [32]. Within this category, poloxamer P403 is a prospective material due to its high ratio of PPO (as compared to poloxamer P407, pluronic F127), low critical micelle concentration (CMC) value, and considerable internal space [33]. The poloxamer-based drug-carrier system can also achieve higher oral availability by inhibiting the drug efflux mediated by P-glycoprotein [34].

Currently, poloxamer has often been conjugated with several biocompatible polymers, such as chitosan, gelatin, heparin, polyacrylic, dendrimer, etc. [31,35,36]. It is because poloxamer micelles alone couldn't provide a durable, long-term drug-release profile; some even exhibit low biocompatibility. The grafted copolymers serve as multifunctional nanogel platforms for delivering various bioactive molecules while amplifying their biological interactions [30,34,37-40]. Heparin-based platforms exhibited a prominent potential for clinical applications due to their high biocompatibility and inherent interactions with cells $[30,34,41]$. Heparin is readily used in chemotherapy due to its high binding affinity to angiogenic growth factors that tumor tissues often overexpressed $[42,43]$.

In this work, amphiphilic heparin-conjugated poloxamer P403 (HP403) nanogel was developed as carrier systems for $\mathrm{CisOH}$ and $\mathrm{Cur}$. The physicochemical properties of the nano-carriers-particle size, drug entrapment efficiencies (EE), drug delivery efficiency (DL), and drug release-were characterized. In vitro cytotoxicity and in vivo assays were investigated in human breast cancer cell lines (MCF-7 cells) and xenograft assay models, respectively. The result could partially clarify the synergistic effect of aquated cisplatin and Cur in a well-designed delivery platform in antitumor activity.

\section{Results and Discussion}

\subsection{Characterizations of the Amphiphilic HP403 Copolymer}

The characteristic resonance peaks of the p-nitrophenyl chloroformate (NPC)-activated P403 appear at 1.10 and 3.35-3.70 ppm in ${ }^{1} \mathrm{H}-\mathrm{NMR}$ (Figure 1A). The aromatic proton signals of NPC moiety resonate at $7.39 \mathrm{ppm}(\mathrm{m})$ and $8.27 \mathrm{ppm}(\mathrm{l})$. The activation of the NPC molecule and P403 was confirmed with a new signal at 4.45 ppm (f) $[44,45]$. The chemical shift from 4.45 ppm (f) to $4.22 \mathrm{ppm}(\mathrm{k})$ occurs due to the NPC substitution by 3-amino-1-propanol, which indicates the successful synthesis of NPC-P403-OH. The ${ }^{1} \mathrm{H}-$ NMR spectrum of aminated heparin H-DAB (Figure 1B) shows the resonance signal at 1.59-1.75 ppm (i) characterized for methylene proton $\left(-\mathrm{CH}_{2}-\right)$ on DAB [46]. The combination of heparin and DAB resulted in a signal of $-\mathrm{CH}_{2}-\mathrm{NH}-$ at 2.88-3.03 ppm (j), which belongs to the binding site of heparin and DAB carboxylate [47]. There are also signals for 
heparin proton at $1.99 \mathrm{ppm}$ and $3.22-5.33 \mathrm{ppm}[29,48]$. The evidence indicates the successful synthesis of H-DAB. Figure $1 \mathrm{C}$ shows the ${ }^{1} \mathrm{H}-\mathrm{NMR}$ spectrum of HP403. Characteristic signals of $\mathrm{P} 403$ were $1.09 \mathrm{ppm}$ (a) and $3.67 \mathrm{ppm}$ (b), corresponding to the resonance of the $-\mathrm{CH}_{3}$ proton in $\mathrm{PPO}$ and the $\mathrm{OCH}_{2}-\mathrm{CH}_{2} \mathrm{O}$ - proton in PEO. Proton signals of heparin appeared at $1.99 \mathrm{ppm}$ and 3.22-5.32 ppm. Notably, the linkage between H-DAB and NPC$\mathrm{P} 403-\mathrm{OH}$ resulted in the resonance of methylene protons $\left(-\mathrm{CH}_{2}-\mathrm{CH}_{2}\right.$ and $\left.-\mathrm{CH}_{2}-\mathrm{NH}\right)$ at $1.74 \mathrm{ppm}$ (i) and $3.11 \mathrm{ppm}$ (j). In addition, there was no signal of aromatic protons of NPC. The signal performing a direct bond between the methylene and carbonate group of NPC $\left(-\mathrm{CH}_{2}-\mathrm{O}-\mathrm{NPC}\right)$ at $4.43 \mathrm{ppm}(\mathrm{f})$ did not occur. The only signal recorded at $4.22 \mathrm{ppm}(\mathrm{k})$ belongs to methylene protons of $\mathrm{CH}_{2}-\mathrm{O}-\mathrm{Ami}$ linkage. This result proves that NPC moiety was substituted by $\mathrm{H}-\mathrm{DAB}$ amine groups in the grafted process of two polymers.

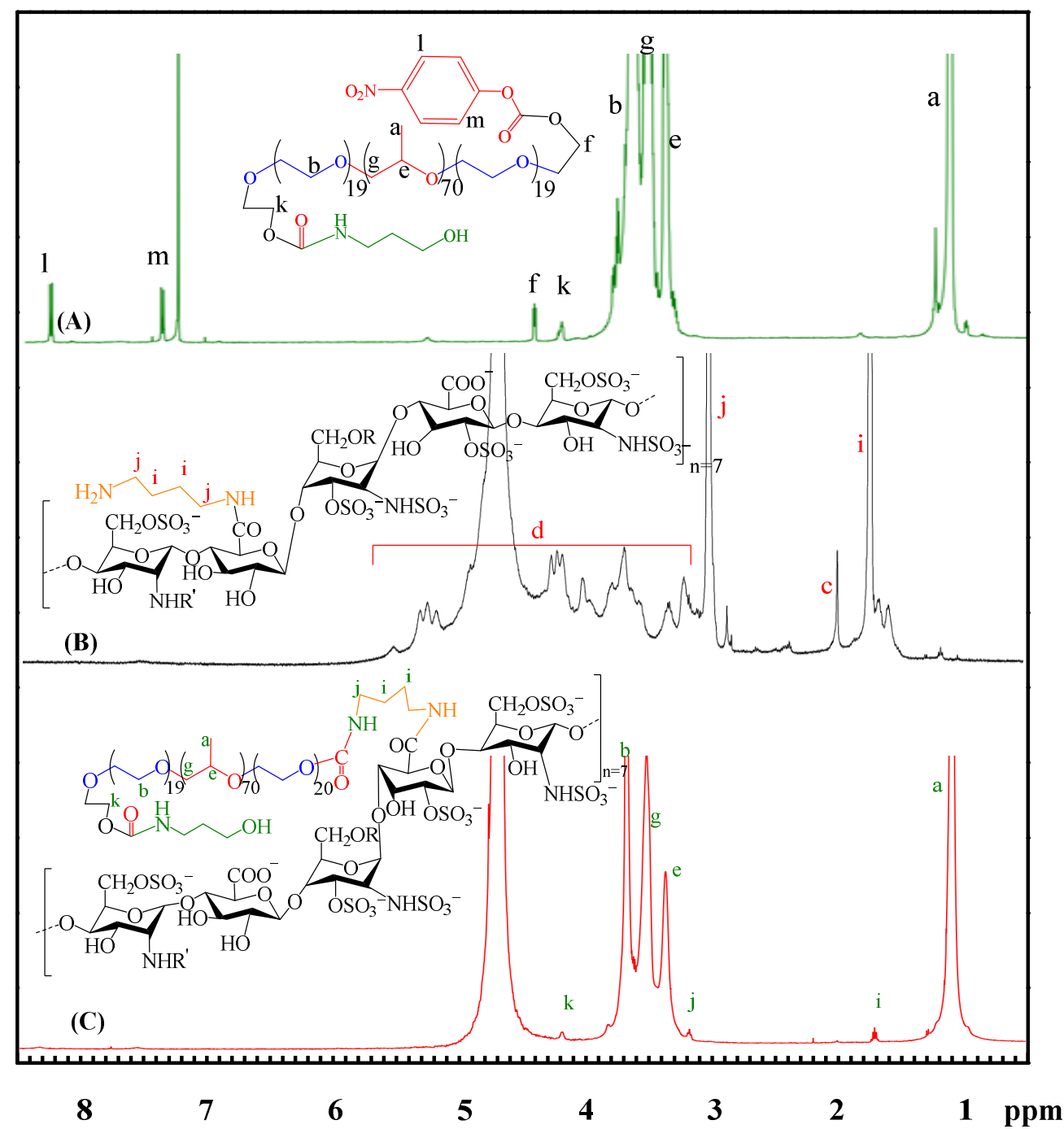

Figure 1. ${ }^{1} \mathrm{H}$ NMR spectra of NPC-P403-OH (A); H-DAB (B); HP403 (C).

\subsection{Size Distribution and CMC Value of HP403}

The TEM result in Figure 2 shows that the HP403 nanogel has spherical shapes with an average particle size of $61.4 \pm 20.2 \mathrm{~nm}$. The average particle size measured by DLS shown in Figure $2 \mathrm{C}$ ranged $94.12 \pm 3.85 \mathrm{~nm}$ at $25^{\circ} \mathrm{C}$ with $\mathrm{PI}=0.39 \pm 0.07$, which indicated that the nanogel system has high stability (Figure 2D). 

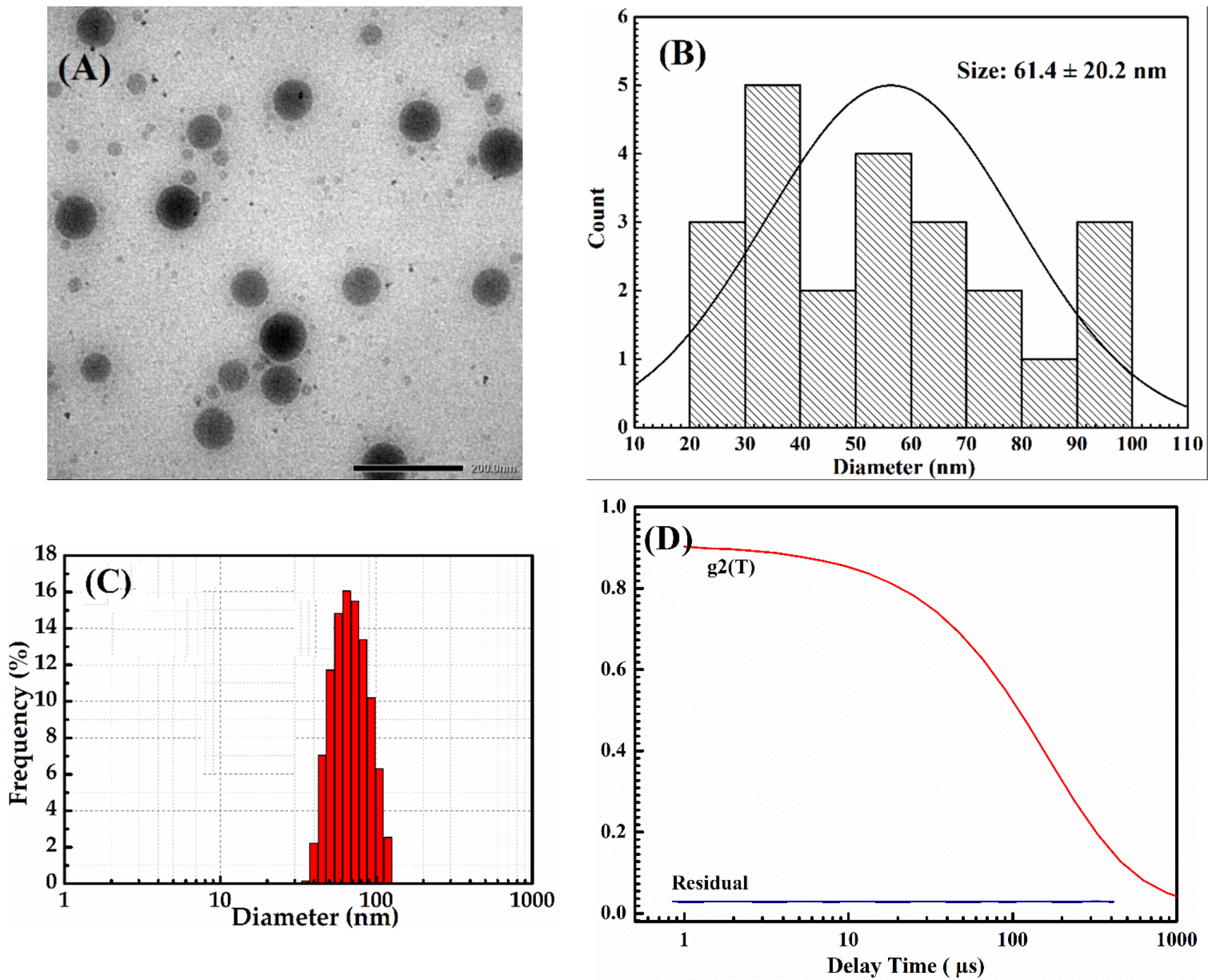

Figure 2. TEM image (A), diameter histogram (B), DLS particle size distribution (C), and stability (D) of the HP403 nanogel.

The CMC of the HP403 copolymer was $40.97 \pm 4.04 \mathrm{ppm}$, measured with iodine and UV-Vis spectroscopy. CMC is a crucial parameter to the nanogel formation of amphiphilic copolymers, especially in drug-delivery applications. The assembling of micelles through hydrophobic interactions helps to balance and stabilize drug release [49]. Within the HP403 structure, P403 is responsible for micelle self-assembly. Insoluble drugs are contained in the PPO hydrophobic core of poloxamer. The complex is shielded by the hydrophilic regions consisting of $\mathrm{PEO}$ and heparin with hydrogen bonding or electrostatic interactions. This unique structure makes nanogels an ideal and highly stable drug delivery system $[30,50]$.

\subsection{Drug Entrapment Efficiency and Loading Efficiency of HP403}

In this experiment, Cur was loaded into HP403 copolymer through hydrophobic interactions between Cur and PPO regions of $\mathrm{P} 403$. CisOH was complexed to carboxylate/sulfate groups on heparin. The structure and encapsulation efficiency of HP403 towards Cur and $\mathrm{CisOH}$ were determined through FT-IR, UV-Vis and ICP-MS spectroscopy (Nex-ION 2000, Perkin Elmer, Waltham, MA, USA).

FT-IR spectra in Figure 3 show the typical signals of both heparin and P403: peaks $2951.95 \mathrm{~cm}^{-1}$ and $2874.03 \mathrm{~cm}^{-1}$ belongs to the $\mathrm{C}-\mathrm{H}$ valence oscillations of $-\mathrm{CH}_{2}$ and $-\mathrm{CH}_{3}$ groups on poloxamer P403; peaks $3434.99 \mathrm{~cm}^{-1}$ and $3285.97 \mathrm{~cm}^{-1}$ are the $-\mathrm{OH}$ and $-\mathrm{NH}$ valence vibrations on the Cis molecule, respectively [51]. A new absorption oscillation 
appeared in the HP403@CisOH spectrum at $1712.01 \mathrm{~cm}^{-1}(\mathrm{~A})$. The signal indicated a complex formed between $\mathrm{CisOH}$ and the heparin carboxylate group, which shifted the $\mathrm{C}=\mathrm{O}$ carboxylate signal from $1631.89 \mathrm{~cm}^{-1}$ to $1712.01 \mathrm{~cm}^{-1}$. Furthermore, two new infrared absorption bands in HP403@CisOHs spectrum at $1298.02 \mathrm{~cm}^{-1}$ (B) and $845.96 \mathrm{~cm}^{-1}$ (C) are symmetric valence vibration of $\mathrm{S}=\mathrm{O}$ bond due to the complex formation sulfate group and a part of the sulfonate group on heparin with $\mathrm{CisOH}$ [52]. The FT-IR spectroscopy in Figure 3 demonstrates the successful synthesis of HP403@CisOH product within the simultaneous appearance of $\mathrm{HP} 403, \mathrm{CisOH}$, and the complex of $\mathrm{CisOH}$ and anionic groups on heparin. Furthermore, the spectrum of HP403@CisOH@Cur contained characteristic signals of both HP403@CisOH and Cur (peak $1627.98 \mathrm{~cm}^{-1}$ for $\mathrm{C}=\mathrm{C}$ aromatic ring, peak $1509.02 \mathrm{~cm}^{-1}$ for $\mathrm{C}=\mathrm{O}$ and $\mathrm{C}=\mathrm{C}$ ) [53]. The result proves that $\mathrm{Cur}$ was loaded and encapsulated in the HP403@CisOH nanogel system, and the HP403@CisOH@Cur nanoparticles were successfully synthesized. The DL and EE results of HP403@CisOH@Cur were calculated from formulas (1) và (2) in Section 4.3 shows that HP403@CisOH could load up to 30.39\% and 75.98\% CisOH, respectively. While the HP403@CisOH@Cur system successfully encapsulated 22.3\% (DL) and 55.75\% (EE) of $\mathrm{CisOH}$; and 4.4\% (DL) and 88\% (EE) for Cur.
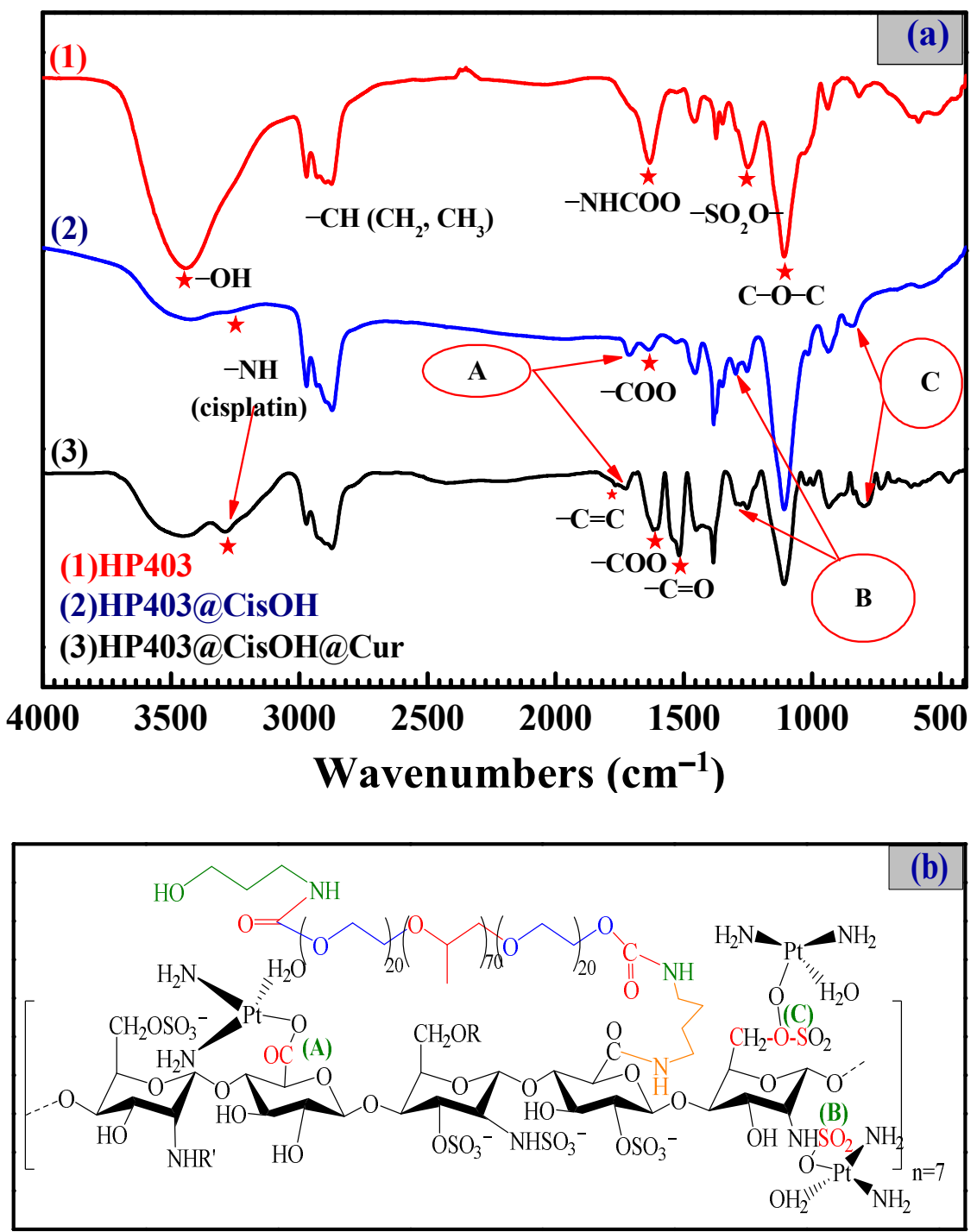

Figure 3. FT-IR spectra of heparin, HP403, HP403@CisOH and HP403@CisOH @Cur (a); Simple illustration of HP403@CisOH complex (b). 
TEM images were used to evaluate the morphology of HP403@CisOH@Cur nanoparticles. Figure 4 shows that HP403@CisOH@Cur had an average particle size of $125.72 \pm 18.01 \mathrm{~nm}$. The DLS result of HP403@CisOH@Cur nanogel was $162.9 \mathrm{~nm}$ with PI =0.27, indicate the sample has high stability. An increment in dual drug-loaded nanogels was recorded due to loading a high amount of Cur in the hydrophobic domains and platinum complex formation resulting in expanding its particle size.
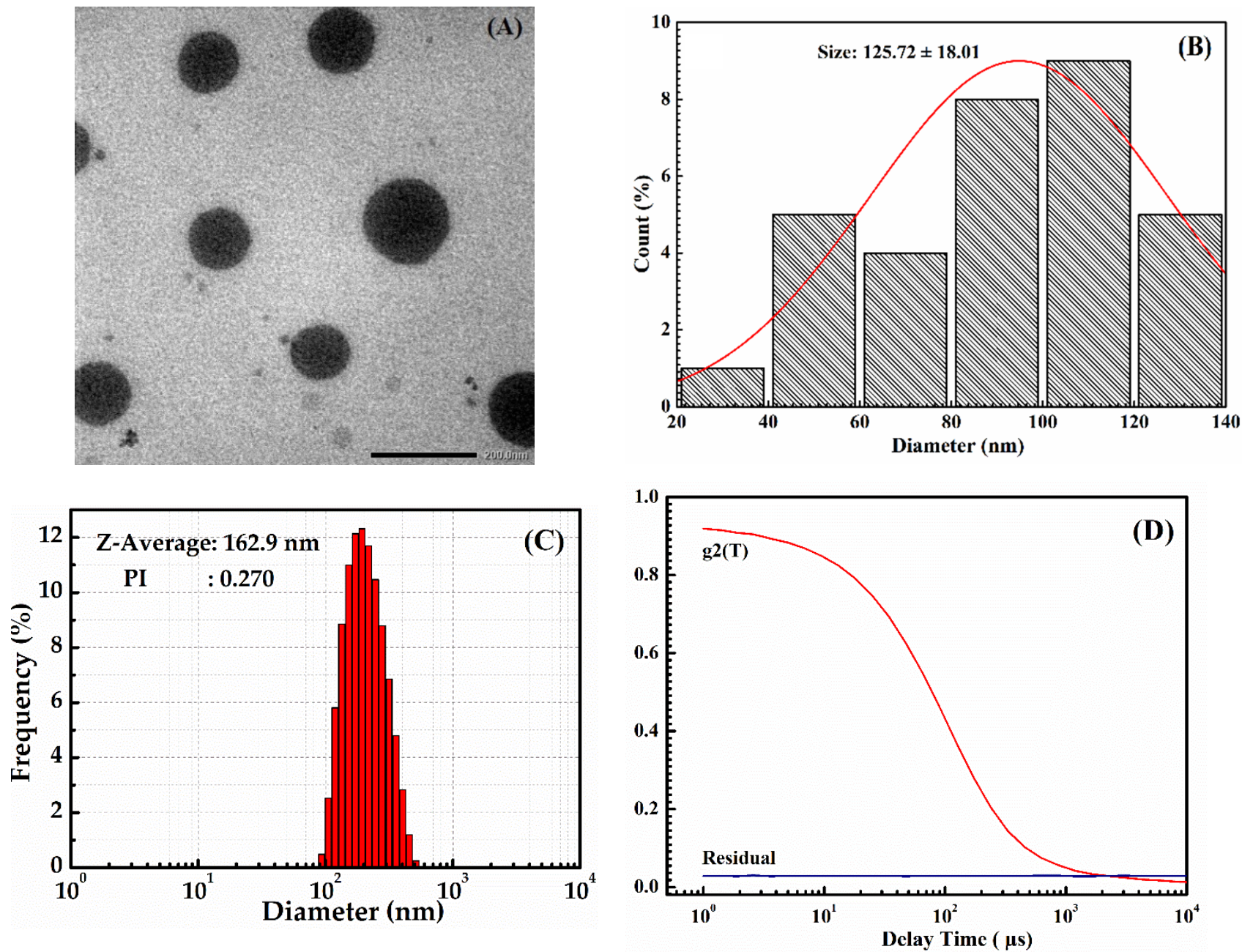

Figure 4. TEM image (A), diameter histogram (B), DLS particle size distribution (C), and stability (D) of the HP403@CisOH@Cur nanogel.

\subsection{In Vitro Drug-Release Assay and Drug-Release Kinetics}

The release of $\mathrm{CisOH}$ and Cur from the nanogel was investigated at $\mathrm{pH} 5.5$ and 7.4. Figure $5 \mathrm{~A}$ shows that, in the first $12 \mathrm{~h}$, about $37.91 \%$ and $42.15 \%$ of Cur were released at pH 7.4 and 5.5, respectively. There was no burst drug release at this early stage, indicating that Cur was not adsorbed on the surface of the nanogel and was completely enclosed within the hydrophobic structural region of the nanogel. This resulted in a slow and sustained release of curcumin during the first $12 \mathrm{~h}$ at both $\mathrm{pH}$ media. The rate of Cur release then gradually increased over the next $84 \mathrm{~h}$; higher Cur release was observed at $\mathrm{pH}$ 5.5. Approximately $75.70 \%$ of Cur was released at $\mathrm{pH} 5.5$ and $59.04 \%$ of Cur was released at pH 7.4 after 96 h. Figure 5 shows that $\mathrm{CisOH}$ and $\mathrm{Cur}$ are both released more efficiently at $\mathrm{pH}$ 5.5. The acidic environment helped to accelerate the release of drugs, especially $\mathrm{CisOH}$. It was beneficial for the system's activities because tumors usually have a lower $\mathrm{pH}$ than healthy tissue. This result also corresponded to some previous publications of platinum carrier systems [54,55]. Figure 5B CisOH was not completely released from 
the HP403@CisOH@Cur system after 96 h. The release rate of $\mathrm{CisOH}$ only reached 68\% in pH 5.5 and 47.43\% in pH 7.4, which lead to the conclusion that HP403@CisOH@Cur was a potential slow-release carrier system. The drug-releasing process was inhibited by the complex between Cis and heparin's carboxylate/sulfate groups, as well as the conjugation between $\mathrm{CisOH}$ and the amine/amide groups of heparin [53,56]. In the blood circulation ( $\mathrm{pH}$ 7.4), the bonds in the carrier system are stabilized to prevent unwanted toxicity and non-specific effects of the drug. Once the drug-loading systems reach tumor tissues, the drug is rapidly released by the reaction of HP403@CisOH@Cur in the acidic environment of the tumor.
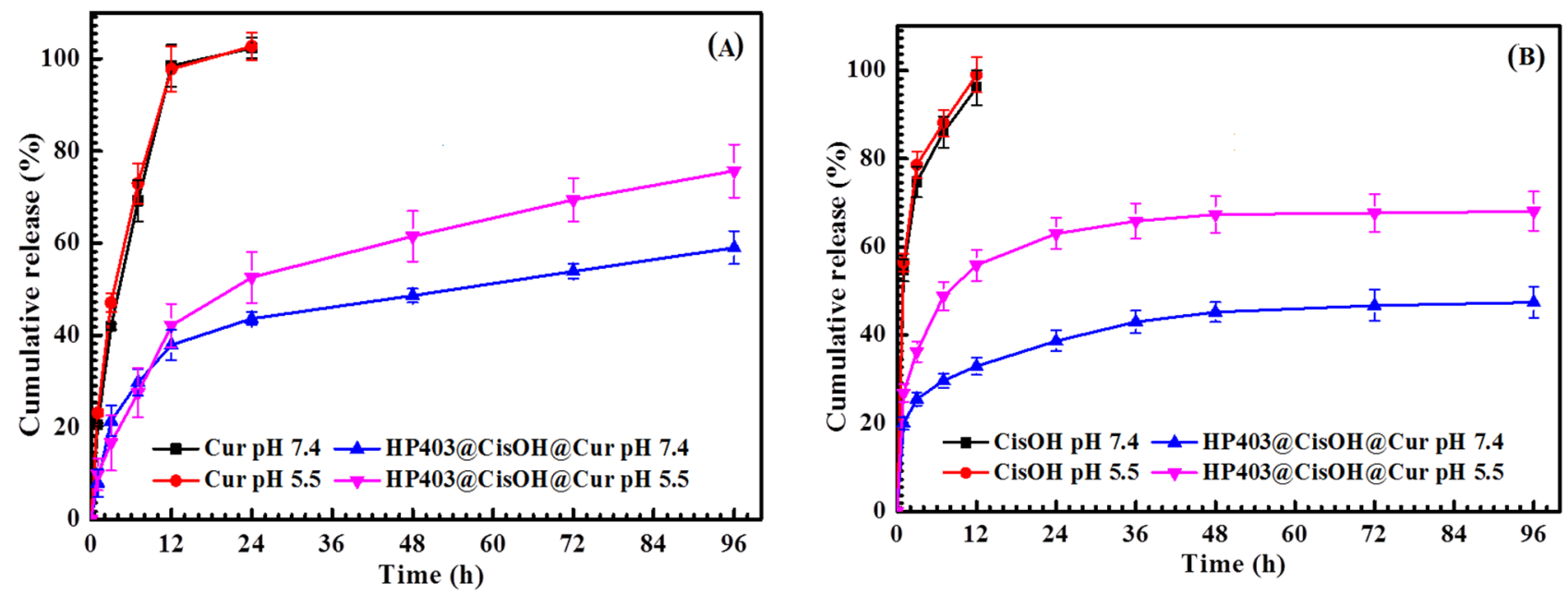

Figure 5. Released profiles of Cur (A) and $\mathrm{CisOH}$ (B) from the HP403@CisOH@Cur drug-loading system and control samples at physiological conditions, pH 5.5 and $\mathrm{pH} 7.4\left(37 \pm 1{ }^{\circ} \mathrm{C} ; \mathrm{n}=3\right)$.

Drug delivery systems aim to overcome the problems of retention, release, activation, localization, and drug targeting with precise timing, dosage, and location. Biodegradable polymers are used as drug transporters in vitro or in vivo. By tuning their structure and drug release, we can control the kinetics of those drug carriers. The drug release kinetics of HP403 nanogel have been studied to understand the release mechanism of $\mathrm{CisOH}$ and Cur in vitro as a premise for future in vivo tests. Experimental data on the release of Cur and $\mathrm{CisOH}$ were processed through Solver and Data Analysis programs. The $\mathrm{k}$ and $\mathrm{R}^{2}$ kinetic constants were shown in Table 1 . Our results showed differences in the value of regression parameters $\mathrm{R}^{2}$. The $\mathrm{R}^{2}$ values of different models followed this order: Korsmeyer-Peppas $>$ Higuchi $>$ Zero-order $>$ First-order. The release of $\mathrm{CisOH}$ and Cur from HP403@CisOH@Cur at pH 7.4 and pH 5.5 followed the Korsmeyer-Peppas model. The diffusion exponent (n) of the system ranges from 0.2056 to 0.4271 , calculated from the Korsmeyer-Peppas kinetic equation. Table 1 showed $\mathrm{n}<0.45$, indicating that $\mathrm{CisOH}$ and Cur were released from HP403@CisOH@Cur following Fickian diffusion [57,58].

The changes in particle size and PDI of HP403@CisOH@Cur after redispersion in an aqueous medium for $96 \mathrm{~h}$ were shown in Figure 6 . At $72 \mathrm{~h}$, there was no significant change. The particle size was less than $250 \mathrm{~nm}$, and the PDI was less than 0.5 . The results indicated a narrow size distribution of HP403@CisOH@Cur after redispersion in an aqueous medium at $72 \mathrm{~h}$. At $96 \mathrm{~h}$, particle size and PDI increased to more than $300 \mathrm{~nm}$ and more than 0.8, respectively. Our results show that HP403@CisOH@Cur can maintain its structural stability in an aqueous medium for $72 \mathrm{~h}$. 
Table 1. Release parameters for Cur and CisOH of HP403@CisOH@Cur were obtained after fitting the drug-release data to four different mathematical models of drug release kinetics.

\begin{tabular}{|c|c|c|c|c|c|c|c|c|c|c|}
\hline \multirow{3}{*}{ Cur Formulation } & \multirow{3}{*}{$\mathrm{pH}$} & \multicolumn{9}{|c|}{ Mathematical Models for Drug-Release Kinetics } \\
\hline & & \multicolumn{2}{|c|}{ Zero Order } & \multicolumn{2}{|c|}{ First Order } & \multicolumn{2}{|c|}{ Higuchi } & \multicolumn{3}{|c|}{ Power Law } \\
\hline & & $k_{0}$ & $R^{2}$ & $k_{1}$ & $R^{2}$ & $k_{H}$ & $R^{2}$ & K & $n$ & $R^{2}$ \\
\hline Free Cur & pH 5.5 & 0.5537 & 0.8730 & 0.1318 & 0.8011 & 1.1075 & 0.8730 & 3.1978 & 0.3933 & 0.9629 \\
\hline HP403@CisOH@Cur & pH 5.5 & 0.0986 & 0.8957 & 0.0278 & 0.7948 & 0.1972 & 0.9097 & 1.2726 & 0.4225 & 0.9801 \\
\hline Free Cur & pH 7.4 & 1.2622 & 0.8779 & 0.1307 & 0.8104 & 1.0962 & 0.8779 & 2.8779 & 0.4271 & 0.9590 \\
\hline HP403@CisOH@Cur & $\mathrm{pH} 7.4$ & 0.0782 & 0.8430 & 0.0245 & 0.8104 & 0.1563 & 0.8430 & 1.5877 & 0.2929 & 0.9748 \\
\hline \multirow{3}{*}{ Cis Formulation } & \multirow{3}{*}{$\mathrm{pH}$} & \multicolumn{9}{|c|}{ Mathematical Models for Drug-Release Kinetics } \\
\hline & & \multicolumn{2}{|c|}{ Zero Order } & \multicolumn{2}{|c|}{ First Order } & \multicolumn{2}{|c|}{ Higuchi } & \multicolumn{3}{|c|}{ Power Law } \\
\hline & & $k_{0}$ & $R^{2}$ & $k_{1}$ & $R^{2}$ & $k_{H}$ & $R^{2}$ & $k$ & $n$ & $R^{2}$ \\
\hline Free $\mathrm{CisOH}$ & pH 5.5 & 1.0435 & 0.9746 & 0.2614 & 0.9569 & 2.0870 & 0.9746 & 5.2155 & 0.2433 & 0.9880 \\
\hline HP403@CisOH@Cur & pH 5.5 & 0.1047 & 0.7598 & 0.0395 & 0.7519 & 1.0624 & 0.9141 & 2.7966 & 0.2646 & 0.9579 \\
\hline Free $\mathrm{CisOH}$ & pH 7.4 & 1.0797 & 0.9719 & 0.2657 & 0.9498 & 2.1594 & 0.9719 & 5.4818 & 0.2359 & 0.9992 \\
\hline HP403@CisOH@Cur & $\mathrm{pH} 7.4$ & 0.0706 & 0.8752 & 0.0307 & 0.8641 & 0.6281 & 0.9615 & 1.9985 & 0.2056 & 0.9965 \\
\hline
\end{tabular}

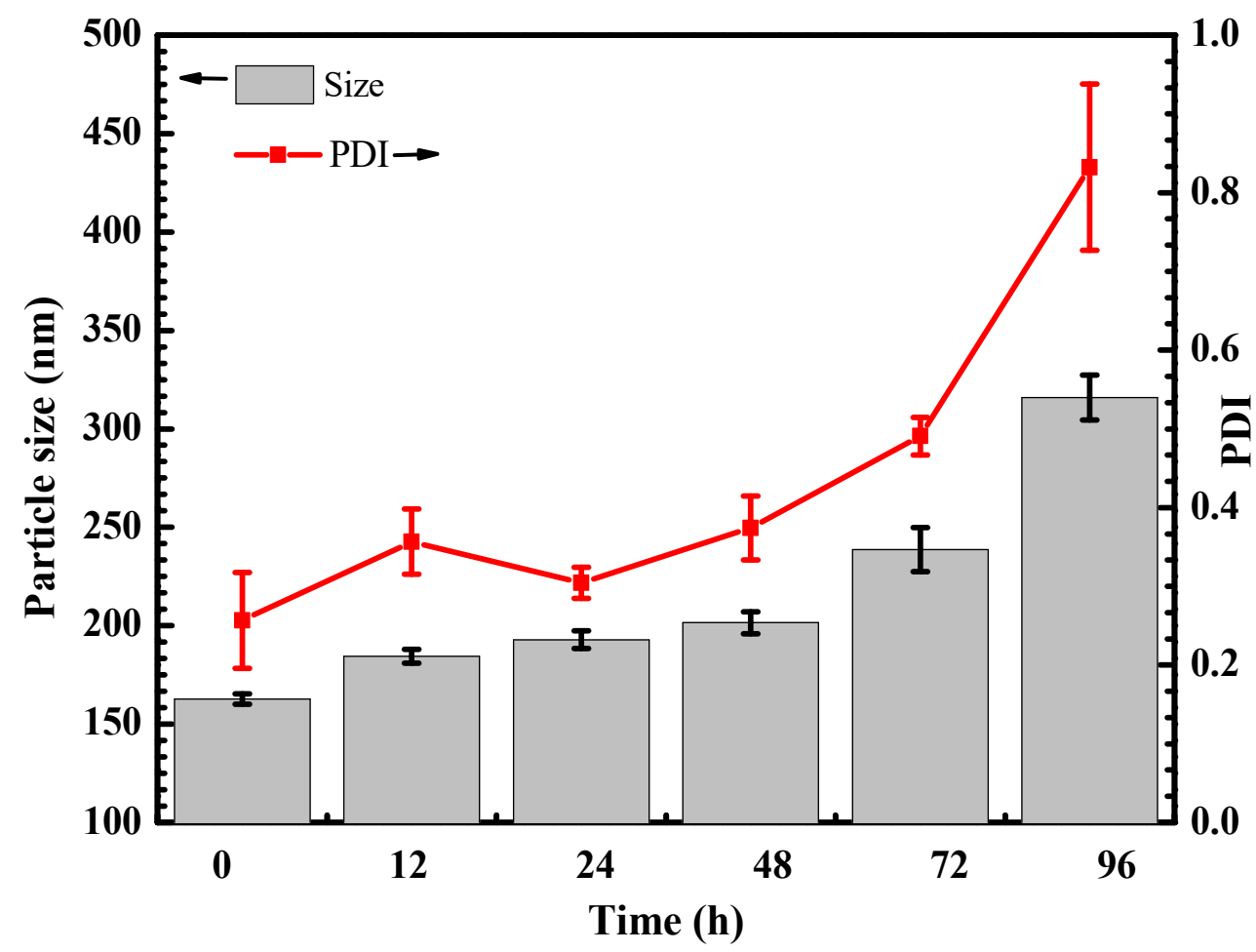

Figure 6. Particle size and PDI of HP403@CisOH@Cur over time after redispersion in an aqueous medium at $37^{\circ} \mathrm{C}$.

\subsection{Cytotoxicity of HP403@CisOH@Cur Nanogels}

The biocompatibility of the HP403 carrier system is evaluated via SRB staining on fibroblasts. The results show that the cell survival rate reached $90 \%$ at $48 \mathrm{~h}$ after exposure to $100 \mu \mathrm{g} / \mathrm{mL}$ HP403. Therefore, the HP403 carrier was biocompatible and non-toxic. In contrast, Cis was extremely lethal to normal cells, with $\mathrm{IC}_{50}=0.61 \pm 0.03 \mu \mathrm{g} / \mathrm{mL}$. Many clinical studies have also reported that Cis attacks both cancer and healthy tissues, causing severe side effects to patients taking chemotherapy drugs. However, once the drug is 
loaded into nanogel carrier systems in $\mathrm{CisOH}$ form, the hydrolysis of the complex inside the nanogel causes a slow release of the cisplatin hydrate. This process can reduce the toxicity of the Cis and may prolong drug bioavailability.

The cytotoxicity assay of HP403@CisOH and HP403@CisOH@Cur on the breast cancer cell line MCF-7 was performed by SRB staining, as shown in Figure 7 . After $48 \mathrm{~h}$, drugloaded HP403 nanogels exhibited high inhibition towards MCF-7 cells. At $10 \mu \mathrm{g} / \mathrm{mL}$, the $\mathrm{HP} 403 @ \mathrm{CisOH}$ system has a cytotoxic percentage of $52.76 \pm 2.53 \%$, higher than $40.45 \pm 1.3 \%$ of HP403@CisOH@Cur. The above results indicated that the $\mathrm{CisOH}$ and Cur combination could reduce the side effects of $\mathrm{CisOH}$ but diminish the cytotoxic potential towards MCF-7 cancer cells of the drug-carrying nanogel system. $\mathrm{IC}_{50}$ value of $\mathrm{HP} 403 @ \mathrm{CisOH}$ is $8.5 \pm 0.7 \mu \mathrm{g} / \mathrm{mL}$, which is smaller than $19.99 \pm 0.89 \mu \mathrm{g} / \mathrm{mL}$ of HP403@CisOH@Cur.
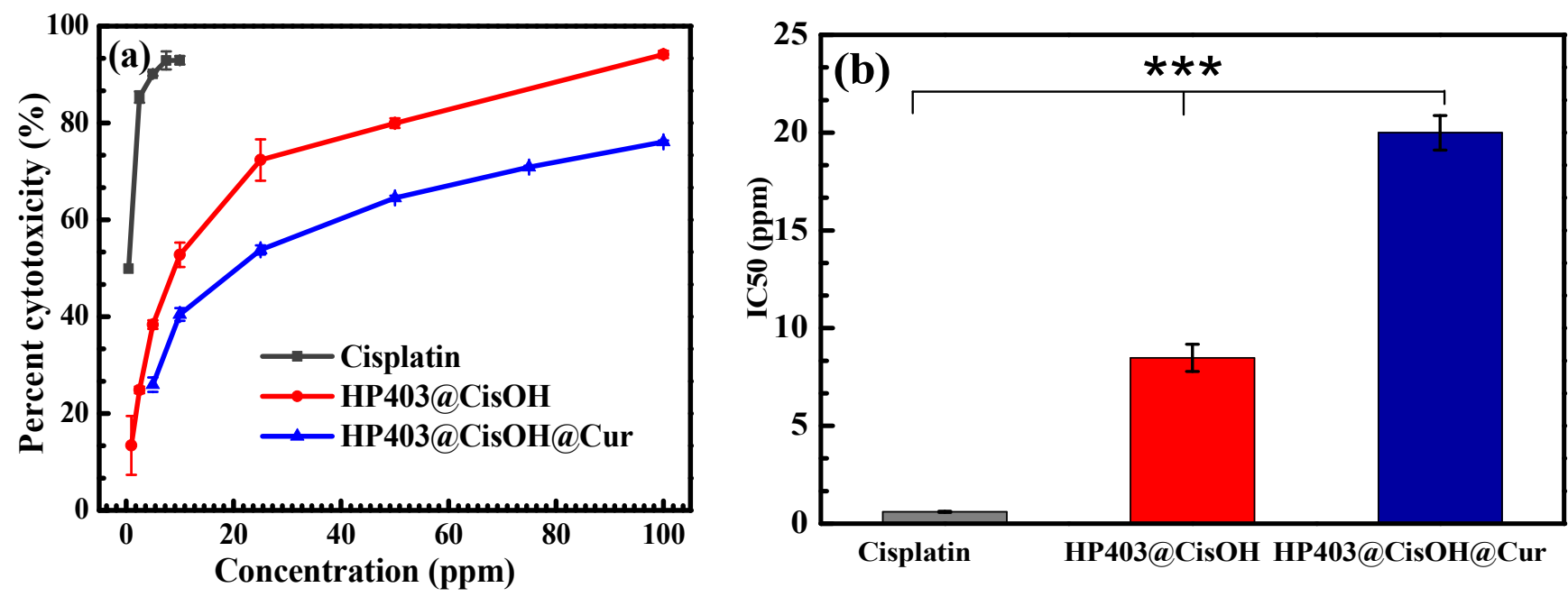

Figure 7. Cytotoxicity of Cis, HP403@CisOH and HP403@CisOH@Cur on MCF-7 cells, in terms of (a) Cell death percentage and (b) IC50 value. (Statistical significance of $p<0.001$ are indicated by ${ }^{* * *}$ ).

The results prove that HP403@CisOH@Cur can provide a synergistic effect against the proliferation of breast cancer cell MCF-7. Cisplatin is a powerful chemotherapeutic agent which induces apoptosis primarily through binding to DNA and inhibiting DNA replication [22]. However, the mechanism is not tumor-specific, and therefore cisplatin often attacks normal tissues during therapy. In addition, Cis resistance was frequently observed throughout the cases, leading to clinical failure [6,7]. Curcumin is an antioxidant with significant anti-inflammatory and anti-neoplastic activities. Several clinical studies have shown that curcumin can attenuate undesirable toxicity caused by cisplatin and reverse cisplatin resistance in cancer cells, which eventually enhances the therapeutic effect [8-10,22-26]. Furthermore, curcumin is rapidly metabolized under physiological conditions; thus, curcumin encapsulation in nanoparticles may contribute to retaining its bioactivity [18-21].

\subsection{Antitumor Effect of HP403@CisOH@Cur Nanogel on Xenografted Mouse Assay}

Mice of uniform weight were used to ensure correlation between treatments. The formulations were injected through their tail veins. Mice body weight and tumor volume were recorded over 13 days. The results are shown in Figures 8 and 9. 


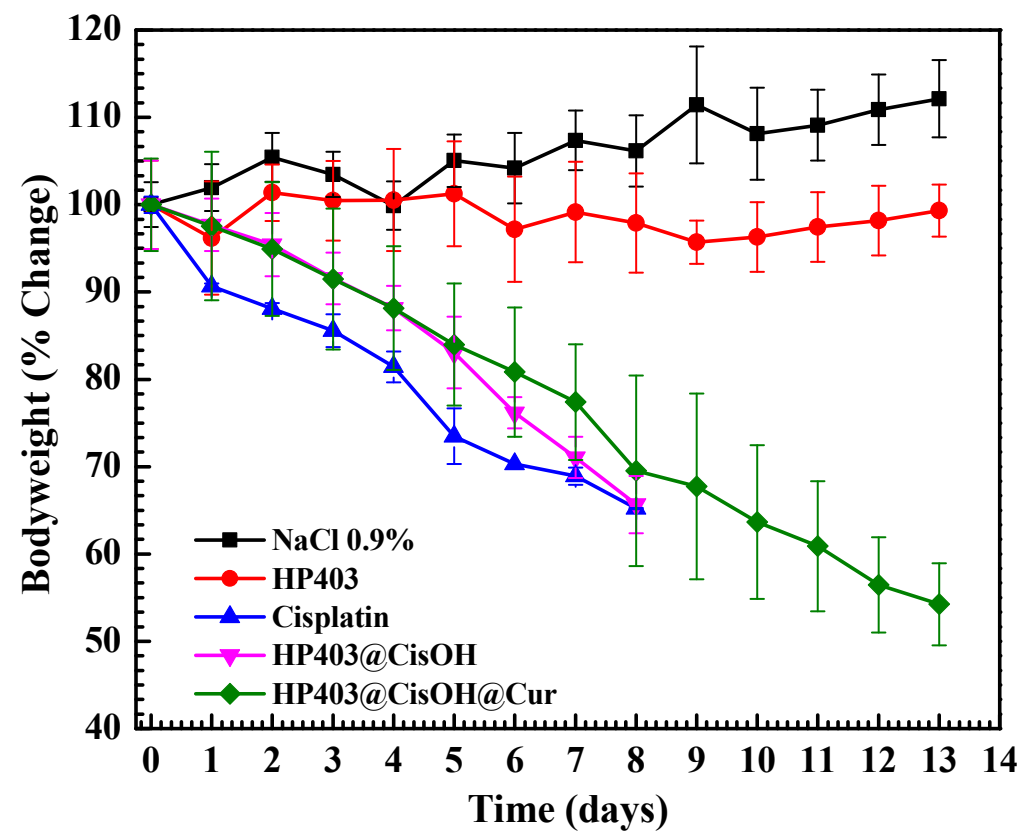

Figure 8. Change in body weight of mice after various formular injections.

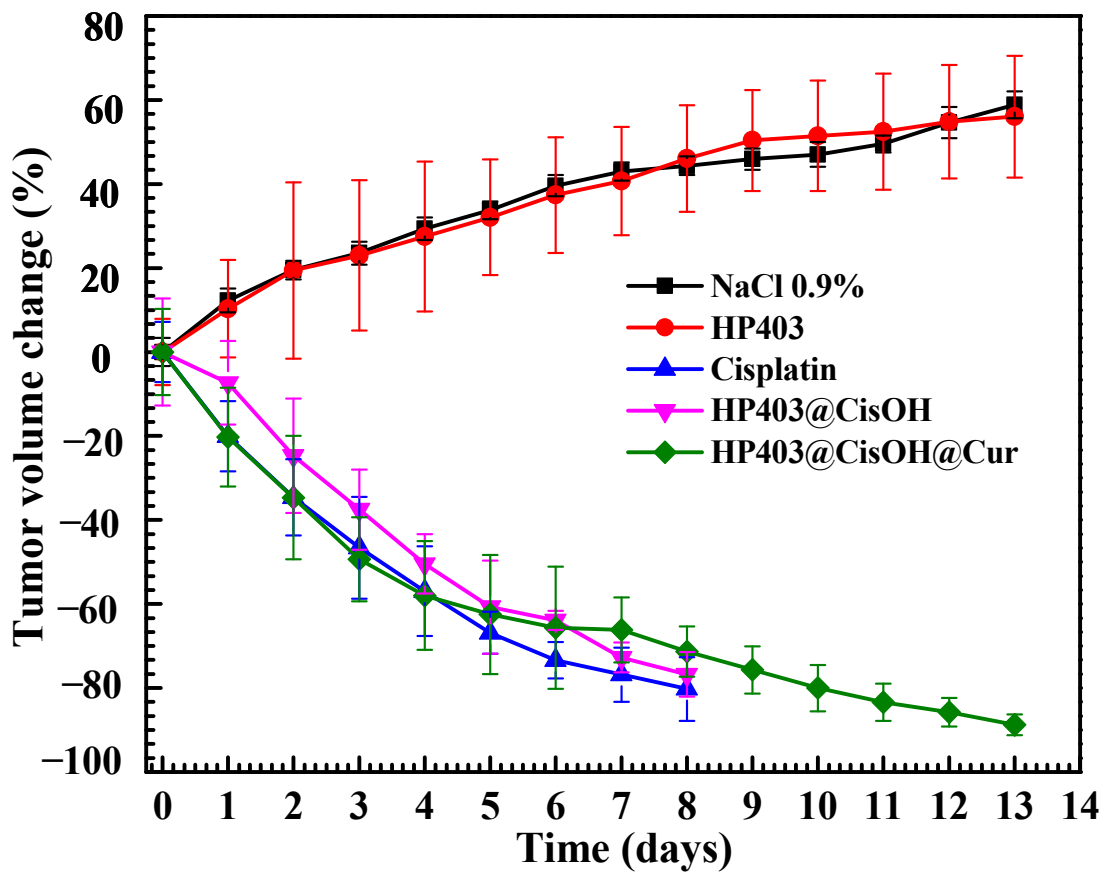

Figure 9. Change in tumor volume of mice after various formular injections.

As shown in Figure 8, mice maintained a stable weight in control $(\mathrm{NaCl} 0.9 \%)$ and HP403 samples. In contrast, there was considerable body mass loss after injecting cisplatin, HP403@CisOH, and HP403@CisOH@Cur. In the cisplatin and HP403@CisOH formulations, there were four dead mice on day eight, which could indicate that the formulated platinum contents could be too high resulting in high toxicity with investigated animals. The same loaded platinum amount in HP403@CisOH@Cur was quite high, reaching 22.3\% (DL) and $55.75 \%$ (EE), which led to a decrease in the nanogel's drug-holding capacity. Moreover, nearly $60 \% \mathrm{CisOH}$ was released rapidly in the first $12 \mathrm{~h}$ at $\mathrm{pH}$ 5.5. These reasons might be responsible for the significant body weight loss after 13 days. Although, there were no mice that died in the treatment regimen after thirteen days, which could partially indicate 
synergistic effect of Cur in the dual delivery system. Further studies should reduce the amount of $\mathrm{CisOH}$ loaded in HP403@CisOH@Cur to increase clinically potential application of the drug delivery system. In Figure 9, we continue to observe two opposite trends: tumor volume was reduced in cisplatin,HP403@CisOH, and HP403@CisOH@Cur treatments but increased in control ( $\mathrm{NaCl} 0.9 \%)$ and $\mathrm{HP} 403$ samples. There were no significant differences between $\mathrm{NaCl}$ and $\mathrm{HP} 403$ samples during the 13 days of testing. Tumors in both cases expanded rapidly and increased by nearly $60 \%$ after the last day. In contrast, tumor reduction was observed in cisplatin, HP403@CisOH, and HP403@CisOH@Cur. On day eight, the tumor decreased by $80 \%, 78 \%$, and $70 \%$ of the original volumes, respectively. Thus, it can be seen that HP403 had significant enhancing effects on the anti-cancer ability of cisplatin. Furthermore, mice injected with HP403@CisOH@Cur can survive to day 13 and achieved $90 \%$ tumor volume loss. It indicated the dual curcumin and cisplatin nanocarrier system was the most effective regimen in inhibiting cancer cells growth.

It was observed in Figure 10C that necrosis occured at the tail area of mice injected with Cisplatin. These may be due to cisplatin's high toxicity and bioaccumulation in the injected sites, causing inflammation that leads to necrosis. In Figure 10D, the tail of mice treated with HP403@CisOH suffered from inflammation and blood congestion. In contrast, the tail appearance of HP403@CisOH@Cur-treated model (Figure 10E) was normal, similar to the control and HP403 samples. Our results correspond with previous studies that reported curcumin's anti-inflammatory activity that contributed to suppressing the side effect [13-15].

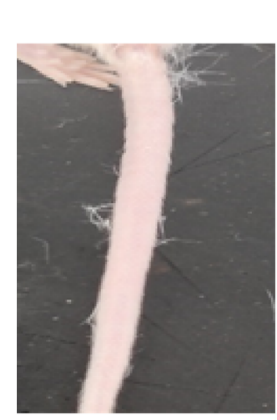

A

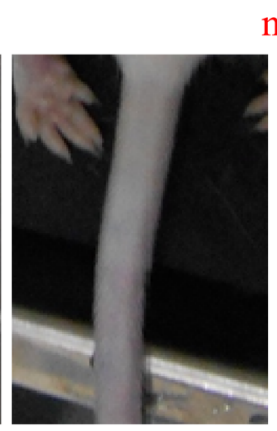

B

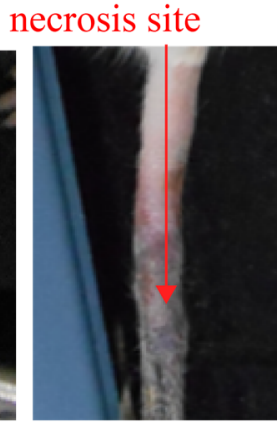

$\mathrm{C}$

inflammatory site

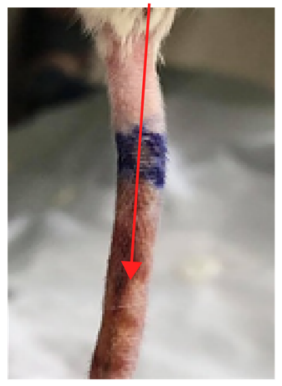

$\mathrm{D}$

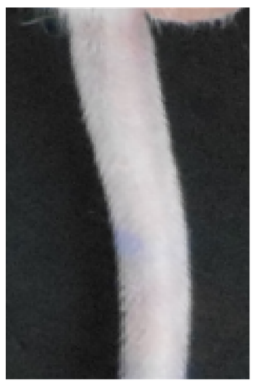

$\mathrm{E}$

Figure 10. Tail at injection site of treatments (A) $\mathrm{NaCl}$ (B) $\mathrm{HP} 403$ (C) Cis (D) HP403@CisOH (E) HP403@CisOH@Cur.

Besides the above assays for tracking the effectiveness of treated models, histological staining is one of the gold standards to evaluate the biopsy of cancer tissue. Hematoxylin and eosin (HE) staining results could further clarify the density of cancer cells in tumor tissue. The HE stained images of the xenografted tumors before treatment (Figure 11A) and after treatment with $\mathrm{NaCl} 0.9 \%$ and $\mathrm{HP} 403$ (Figure 11B,C) show hyperproliferation of MCF-7 cancer cells inside tumor, indicated by their stained nuclei with dark purple color. The proliferation of MCF-7 cells was also confirmed by superoxide dismutase immunohistochemical staining of tumor (data not shown here). In Figure 11D-F, Cis, HP403@CisOH, and HP403@CisOH@Cur treatments inhibited cancer cell proliferation leading to decreased cell density, degraded cytoplasmic region, and shrunk or disappeared nuclei. Compared to Cis and HP403@CisOH-treated models (day 8), the HP403@CisOH@Cur-treated model (day 13) exposed a lesser cell density with acquired lighter purple color. These results could indicate that co-loaded Cur contributed to reduce side-effects of the $\mathrm{Cis}$ and $\mathrm{CiOH}$-treated models and prolong the life span of the mice. 

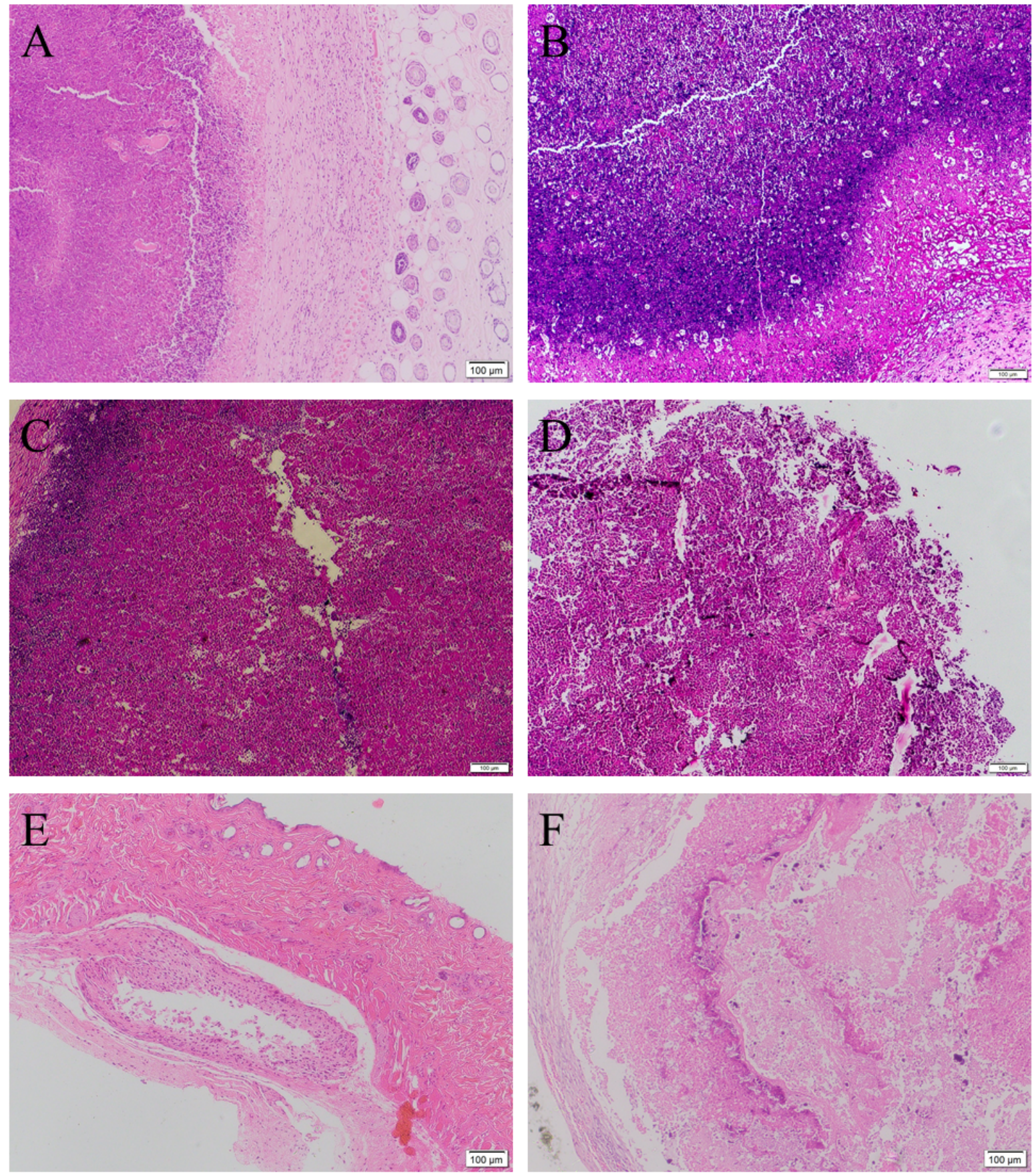

Figure 11. Histological $\mathrm{H} \& \mathrm{E}$ images of tumor tissues before (A) and after treatment with $\mathrm{NaCl}(\mathbf{B})$, HP403 (C), Cis (D), HP403@CisOH (E), and HP403@CisOH@Cur (F).

\section{Conclusions}

In this study, we have developed a biocompatible heparin-poloxamer $\mathrm{P} 403$ platform to efficiently deliver cisplatin (in hydrate form) and Cur via complexation and hydrophobic interaction. The particle size distribution of HP403 was below $100 \mathrm{~nm}$ by (TEM and DLS). $\mathrm{CisOH}$ and Cur were successfully loaded into HP403 nanogel with $22.3 \%$ and $4.4 \%$ efficiency, respectively. In vitro kinetic results of HP403@CisOH@Cur showed that $\mathrm{CisOH}$ and Cur were sustainably released from the nanogel via a diffusion mechanism. The in vitro studies indicated that HP403@CisOH@Cur might provide a synergistic effect against the proliferation of MCF-7 breast cancer cells. According to the in vivo anti-tumor assay using the xenografted mouse model, the HP403@CisOH@Cur nanogel could reduce the tumor 
volume by $90 \%$ without mice dying after being treated for 13 days. The preliminary results indicated that the nanocarrier system of curcumin and cisplatin were highly effective at inhibiting the growth of cancer cells and partially reducing side effect. A further investigation should be proposed with a reduced dosage of the loaded platinum content to significantly reduce drug toxicity and exploit the effects of a dual drug delivery system in cancer treatment.

\section{Materials and Methods}

\subsection{Chemicals}

Acros Organics (USA) provided Heparin sodium, 3-amino-1-propanol (Ami), 1,4diaminobutane $(\mathrm{DAB})$, silver nitrate $\left(\mathrm{AgNO}_{3}\right)$, 1-ethyl-3-3-dimethylaminopropyl carbodiimide (EDC), p-nitrophenyl chloroformate (NPC), N-hydroxysuccinimide (NHS). SigmaAldrich provided cis-Dichlorodiamineplatinum (II) (Cis), 99.99\%, Curcuminoid (Cur), and poloxamer P403. Dialysis membranes (3.5 kDa and 12-14 kDa MW cut-off) were obtained from Repligen Corporation (Rancho Dominguez, Los Angeles, CA, USA).

\subsection{Synthesis of Poloxamer P403-Conjugated Heparin Copolymers (HP403)}

HP403 graft copolymer was prepared through the conjugation between a NPCactivated P403 (NPC-P403-OH) and aminated heparin (H-DAB), as shown in Figure 12.

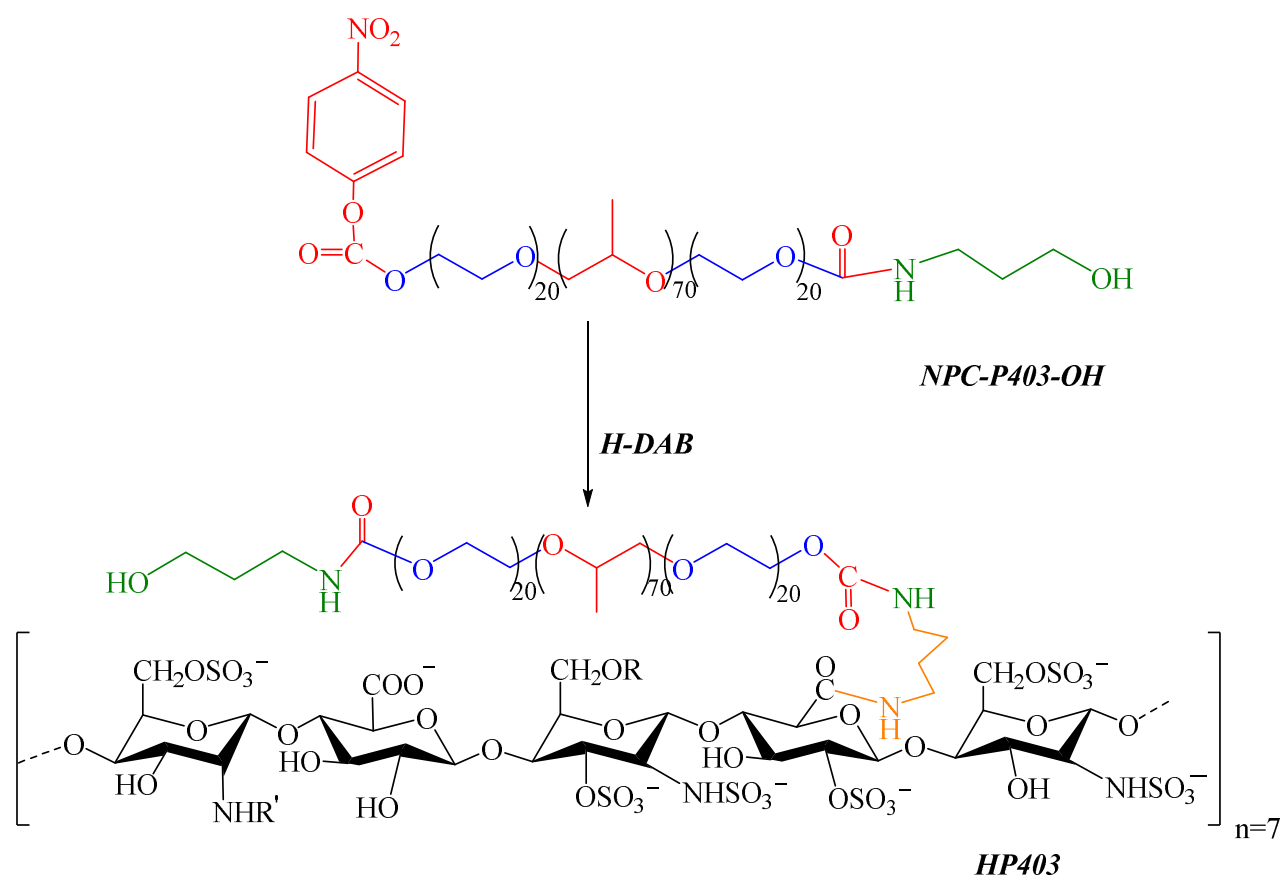

Figure 12. Synthetic scheme of the $\mathrm{HP} 403$ graft copolymer $\left(\mathrm{R}, \mathrm{R}=\mathrm{H}, \mathrm{SO}_{3}{ }^{-}\right.$or $\left.\mathrm{COCH}_{3}\right)$.

\subsubsection{Synthesis of NPC-P403-OH}

P403 (2.5 mmol) was activated with NPC $(7.5 \mathrm{mmol})$ at $70{ }^{\circ} \mathrm{C}$ under vacuuming and stirring. After $8 \mathrm{~h}$, we reduced the temperature back to R.T. and redissolved the sample in $20 \mathrm{~mL}$ THF before precipitating in a diethyl ether:hexane mixture $(1: 1 \mathrm{v} / \mathrm{v})$, repeated three times. NPC-P403-NPC precipitant was obtained after rotary evaporation.

NPC-P403-NPC (1.5 mmol) was dissolved in THF (25 mL). Then, Ami (0.75 mmol in $25 \mathrm{~mL}$ THF) was drop-wised into the NPC-P403-NPC solution under stirring at R.T. for $12 \mathrm{~h}$. NPC-P403-OH precipitant was obtained in viscous form after precipitation in a 1:1 $(v / v)$ mixture of diethyl ether:hexane and rotary evaporation.

The chemical structure of NPC-P403-OH was analyzed via ${ }^{1} \mathrm{H}-\mathrm{NMR}$ spectrometry (Bruker, Billerica, MA, USA). 


\subsubsection{Synthesis of $\mathrm{H}-\mathrm{DAB}$}

DAB-aminated heparin derivatives $(\mathrm{H}: \mathrm{DAB}=1: 3 \mathrm{mmol} / \mathrm{mmol}$ ) with $\mathrm{EDC} / \mathrm{NHS}$ as the carbodiimide coupling reagent.

\subsubsection{Synthesis of HP403 Copolymer}

NPC-P403-OH was dissolved in water at $4{ }^{\circ} \mathrm{C}$ and slowly added to the H-DAB solution. The reaction lasted for $24 \mathrm{~h}$ at $15^{\circ} \mathrm{C}$. The sample was dialyzed with distilled water through the cellulose membrane (MWCO 12-14 kDa) for five days before freeze-drying. Product characteristics, structure, and morphology were determined using ${ }^{1} \mathrm{H}-\mathrm{NMR}$ and TEM. The critical micelle concentration (CMC) was investigated by the iodine probe method $[49,59]$ and calculated via the piecewise function. The data were recorded three times.

\subsection{Synthesis of HP403 Nanogel Coloading Curcumin and Cisplatin Hydrate (CisOH)}

$\mathrm{CisOH}$ preparation referred to our previous reports [34]. In short, the reaction was carried out in an $\mathrm{N}_{2}$ atmosphere at room temperature with degassed DI water. The molar ratio of $\mathrm{AgNO}_{3}(0.88 \mathrm{mmol})$ and $\mathrm{Cis}(0.44 \mathrm{mmol})$ was 2:1. At $48 \mathrm{~h}$ after reaction, $\mathrm{CisOH}$ was obtained after centrifugation to remove the $\mathrm{AgCl}$ precipitate.

Cur $(5 \mathrm{mg})$ was dissolved in $5 \mathrm{~mL}$ ethanol:dichloromethane (DCM) solvent at a ratio of 7:3 $(v / v)$. HP403 $\left(100 \mathrm{mg}\right.$ in $10 \mathrm{~mL}$ solution at $\left.20^{\circ} \mathrm{C}\right)$ under ultrasonic condition was added dropwise into Cur solution ( $30 \mathrm{~min}$, temperature below $20^{\circ} \mathrm{C}$ ). The system was evaporated to remove solvent and dissolved by $5 \mathrm{~mL}$ of water. Then, the sample was centrifuged (15 min, 5000 rpm) and freeze-dried to obtain the HP403@Cur product (Figure 13).

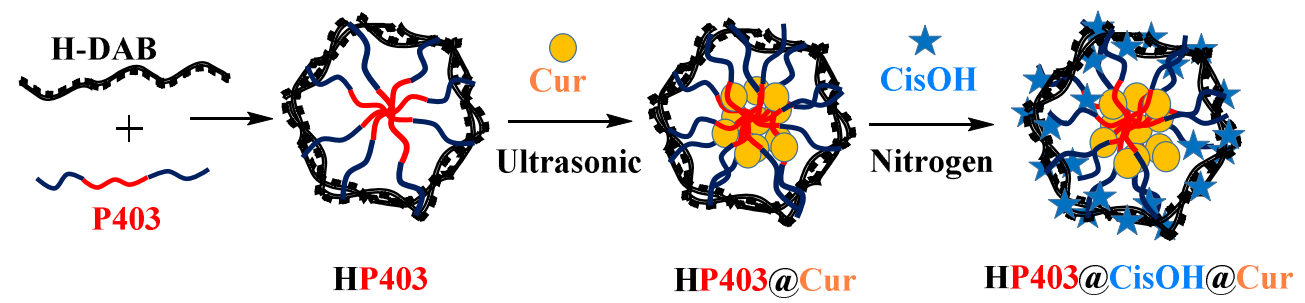

Figure 13. Schematic diagram of HP403 nanogel; HP403@Cur and HP403@CisOH@Cur.

CisOH (40 mg) solution was added dropwise into HP403@Cur products under constant magnetic stirring in a $20{ }^{\circ} \mathrm{C}$ nitrogen atmosphere for $24 \mathrm{~h}$. Then, we dialyzed the achieved solution three times with distilled water at room temperature using cellulose membranes (MWCO $3.5 \mathrm{kDa}, 20 \mathrm{~min} / \mathrm{each}$ ). HP403@CisOH@Cur product was obtained after freeze-drying (Figure 13). Product characteristics, structure, and morphology were analyzed by the Bruker AM500 FT NMR spectrometer (Bruker, Billerica, MA, USA) and TEM-1400 instrument (JEOL Ltd., Tokyo, Japan). The percentage of CisOH and Cur successfully co-loaded into HP403 nanogel was determined by inductively coupled plasma mass spestrometer (ICP-MS, NexION 2000, Perkin Elmer, MA, USA), and UV-Vis (Agilent, Santa Clara, CA, USA). Drug loading (DL\%) and entrapment efficiency (EE\%) of micelle polymer or nanogel were referred to published formulas $[31,33,50]$

$$
\begin{gathered}
\text { EE }(\%)=\frac{\text { Weight of the drug in micelles }}{\text { Weight of the feeding drugs }} \times 100 \% \\
\text { DL }(\%)=\frac{\text { Weight of the drug in micelles }}{\text { Weight of copolymers and drugs }} \times 100 \%
\end{gathered}
$$

4.4. Release Profile and Kinetics of Drugs

4.4.1. The Release Profile of Curcumin

HP403@CisOH@Cur in 2 mL DI water. The control sample was Cur reconstituted in $2 \mathrm{~mL}$ ethanol. Each solution was placed in a dialysis bag (MW cut off $3.5 \mathrm{kDa}$ ) and immersed 
in 20 mL PBS buffer at pH 5.5 and pH 7.4, respectively. Tween 80 was added into the dialysis environment to increase Cur dispersion and prevent its precipitation. The system was magnetically stirred at $100 \mathrm{rpm}, 37^{\circ} \mathrm{C} \pm 1{ }^{\circ} \mathrm{C}$. Cur content measurement was taken with $1 \mathrm{~mL}$ dialysis solution at given time points via an Agilent $8453 \mathrm{UV}$ spectrophotometer (Agilent, Santa Clara, CA, USA). Simultaneously, $1 \mathrm{~mL}$ of PBS buffer containing Tween 80 was added to restore the initial volume. Cur was calculated as follows:

$$
\operatorname{CR}(\%)=\sum_{\mathrm{t}=0}^{\mathrm{t}=\infty} \frac{\mathrm{M}_{\mathrm{t}}}{\mathrm{M}_{0}} \times 100
$$

Of which: $\mathrm{Mt}$ is the amount of Cur in the release environment at $\mathrm{t}$ (hours); $\mathrm{M}_{0}$ is the amount of Cur in HP403@CisOH@Cur. To investigate the Cur-released profile of HP403@CisOH@Cur, we analyzed obtained data with Korsmeyer-Peppas models, firstorder, and zero-order. Regression results were indicated by the regression coefficient $\left(\mathrm{R}^{2}\right)[60,61]$.

\subsubsection{The Release Profile of $\mathrm{CisOH}$}

The methods to study the $\mathrm{CisOH}$ release profile were similar to Cur. However, we prepared $\mathrm{CisOH}$ control samples with $2 \mathrm{~mL}$ DI water. $\mathrm{CisOH}$ contents were determined by platinum measurements via ICP-MS (NexION 2000, Perkin Elmer, MA, USA) (inductively coupled plasma mass spestrometer) and AOAC (association of analytical communities). The $\mathrm{CisOH}$ release experiments were also repeated 3 times.

\subsubsection{Stability Test of HP403@CisOH@Cur Nanogel}

HP403@CisOH@Cur was dispersed in DI water after $96 \mathrm{~h}$ storage at $37^{\circ} \mathrm{C}$. All tests were performed at $37^{\circ} \mathrm{C}$ by DLS HORIBA SZ-100 nanoparticle size analyzer (Horiba Ltd., Kyoto, Japan) to investigate HP403@CisOH@Cur's stability at 0, 12, 24, 48, 72 and 96 h at $37^{\circ} \mathrm{C}$. Experiments were measured in triplicate for each sample, and the results are expressed as mean $\pm \mathrm{SD}$.

\subsection{In Vitro Cytotoxic Assay on MCF-7 Cell Line}

The cytotoxicity assay of HP403, HP403@CisOH and HP403@CisOH@Cur was performed on the breast cancer cell line MCF-7 using SRB assay. [62]. The experiments were conducted at the Molecular Biology Laboratory of the University of Science, Vietnam National University, Ho Chi Minh City, Vietnam. Briefly, $5 \times 10^{3} \mathrm{MCF}-7$ cells were incubated each well in 96-well plates. The $\mathrm{IC}_{50}$ value, inhibitory activity of free Cis, HP403@CisOH, and HP403@CisOH@Cur against MCF-7 proliferation were calculated and compared among samples.

\subsection{In Vivo Anti-Tumor Activity}

Male white mice (Mus musculus var. Albino), at 6-7 weeks old and weighing 25-30 g, were provided by the Stem Cell Institute, University of Sciences, Vietnam National University, HCMC. Mice were raised in laboratory conditions of $20-30{ }^{\circ} \mathrm{C}$, humidity of $30-50 \%$ under a $12 \mathrm{~h}$-light-dark photoperiod.

Methods of creating an immunodeficiency mouse model and mouse model with heterogeneous tumors followed the Department of Animal Physiology and Biotechnology's procedure, University of Sciences, Vietnam National University, HCMC. Animal experiments described in this study were performed in compliance with institutional guidelines and according to protocol approved by the Animal Care and Use Committee of the University of Science under Ethics approval number 500B/KHTN-ACUCUS (9 June 2021).

The total of 25 mice that successfully carried tumors was randomly divided into 5 treatments (5 mice each treatment): physiological saline $\mathrm{NaCl} 0.9 \%$ (100 $\mu \mathrm{L} /$ dose $), \mathrm{HP} 403$ (12 mg per $\mathrm{kg}$ body weight), Cis (3 mg per kg body weight), HP403@CisOH (3 mg Cis per kg body weight), HP403@CisOH@Cur (3 mg Cis per kg body weight, and Cur: HP403 = 5:100 wt/wt). 
The drug was injected through tail veins every 3 days for 13 days with each dose of $3 \mathrm{mg}$ Cis per $\mathrm{kg}$ body weight. Body weight and tumor size were measured daily. The largest and smallest diameter of the tumor was recorded to calculate the tumor volume. At the end of 13 days of the drug trial, tumors were collected and preserved in formalin $10 \%$ solution, then underwent hematoxylin and eosin staining to observe density of tumor cells after various treatments.

\subsection{Data Analysis}

ORIGIN 8.5.1 (OriginLab Inc., Northampton, MA, USA) was used to perform statistical analysis. All experiments were carried out for at least three independent replications and data were expressed as the mean $\pm \mathrm{SD}$. One-way ANOVA or two-way ANOVA tests and Tukey multiple comparison tests were used to determine statistical differences. $\mathrm{A} * p<0.05$, ** $p<0.01,{ }^{* * *} p<0.001$ indicated statistical significance, while ns $p \geq 0.05$ meant that the difference was not statistically significant.

The Materials and Methods should be described with sufficient details to allow others to replicate and build on the published results. Please note that the publication of your manuscript implicates that you must make all materials, data, computer code, and protocols associated with the publication available to readers. Please disclose at the submission stage any restrictions on the availability of materials or information. New methods and protocols should be described in detail while well-established methods can be briefly described and appropriately cited.

Research manuscripts reporting large datasets that are deposited in a publicly available database should specify where the data have been deposited and provide the relevant accession numbers. If the accession numbers have not yet been obtained at the time of submission, please state that they will be provided during review. They must be provided prior to publication.

Interventionary studies involving animals or humans, and other studies that require ethical approval, must list the authority that provided approval and the corresponding ethical approval code.

Author Contributions: Conceptualization, N.T.N., N.Q.T. and D.T.N.; methodology, N.Q.T., N.T.N. D.T.N. and H.L.B.T.; formal analysis, T.T.N., K.L.L., Q.A.B., H.H.N.N., T.T.Y.N., N.H.N. (Ngoc Hao Nguyen) and V.N.D.; investigation, N.T.N. and D.T.N.; resources, N.Q.T., H.L.B.T. and N.T.N.; data curation, D.T.N.; writing—original draft preparation, N.T.N.; writing—review and editing, Q.A.B., N.Q.T., N.H.N. (Ngoc Hoa Nguyen) and D.T.N. All authors have read and agreed to the published version of the manuscript.

Funding: This study was fully supported by Tra Vinh University under grant contract number 175/HĐ.HĐKH-ĐHTV (7 December 2018).

Institutional Review Board Statement: Not applicable.

Informed Consent Statement: Not applicable.

Conflicts of Interest: The authors declare no conflict of interest.

\section{References}

1. Sung, H.; Ferlay, J.; Siegel, R.L.; Laversanne, M.; Soerjomataram, I.; Jemal, A.; Bray, F. Global cancer statistics 2020: GLOBOCAN estimates of incidence and mortality worldwide for 36 cancers in 185 countries. CA Cancer J. Clin. 2021, 71, 209-249. [CrossRef]

2. Li, C.; Ge, X.; Wang, L. Construction and comparison of different nanocarriers for co-delivery of cisplatin and curcumin: A synergistic combination nanotherapy for cervical cancer. Biomed. Pharmacother. 2017, 86, 628-636. [CrossRef]

3. Wexselblatt, E.; Yavin, E.; Gibson, D. Cellular interactions of platinum drugs. Inorg. Chim. Acta 2012, 393, 75-83. [CrossRef]

4. Bostan, M.; Petrică-Matei, G.G.; Radu, N.; Hainarosie, R.; Stefanescu, C.D.; Diaconu, C.C.; Roman, V. The effect of resveratrol or curcumin on head and neck cancer cells sensitivity to the cytotoxic effects of cisplatin. Nutrients 2020, 12, 2596. [CrossRef]

5. Achkar, I.W.; Abdulrahman, N.; Al-Sulaiti, H.; Joseph, J.M.; Uddin, S.; Mraiche, F. Cisplatin based therapy: The role of the mitogen activated protein kinase signaling pathway. J. Transl. Med. 2018, 16, 96. [CrossRef] 
6. $\quad$ Nguyen, N.N.T.; Le, P.N.; Nguyen, T.B.T.; Nguyen, N.H.; Bach, L.G.; Doan, V.N.; Tran, H.L.B.; Le, V.T.; Tran, N.Q. Synergic activity against MCF-7 breast cancer cell growth of nanocurcumin-encapsulated and cisplatin-complexed nanogels. Molecules 2018, 23, 3347. [CrossRef]

7. Zou, J.; Zhu, L.; Jiang, X.; Wang, Y.; Wang, Y.; Wang, X.; Chen, B. Curcumin increases breast cancer cell sensitivity to cisplatin by decreasing FEN1 expression. Oncotarget 2018, 9, 11268. [CrossRef]

8. Wang, Y.; Hu, P.-C.; Gao, F.-F.; Lv, J.-W.; Xu, S.; Kuang, C.-C.; Wei, L.; Zhang, J.-W. The protective effect of curcumin on hepatotoxicity and ultrastructural damage induced by cisplatin. Ultrastruct. Pathol. 2014, 38, 358-362. [CrossRef]

9. Ortega-Domínguez, B.; Aparicio-Trejo, O.E.; García-Arroyo, F.E.; León-Contreras, J.C.; Tapia, E.; Molina-Jijón, E.; HernándezPando, R.; Sánchez-Lozada, L.G.; Barrera-Oviedo, D.; Pedraza-Chaverri, J. Curcumin prevents cisplatin-induced renal alterations in mitochondrial bioenergetics and dynamic. Food Chem. Toxicol. 2017, 107, 373-385. [CrossRef]

10. Ugur, S.; Ulu, R.; Dogukan, A.; Gurel, A.; Yigit, I.P.; Gozel, N.; Aygen, B.; Ilhan, N. The renoprotective effect of curcumin in cisplatin-induced nephrotoxicity. Ren. Fail. 2015, 37, 332-336. [CrossRef]

11. Kumar, G.; Mittal, S.; Sak, K.; Tuli, H.S. Molecular mechanisms underlying chemopreventive potential of curcumin: Current challenges and future perspectives. Life Sci. 2016, 148, 313-328. [CrossRef]

12. Teow, S.-Y.; Liew, K.; Ali, S.A.; Khoo, A.S.-B.; Peh, S.-C. Antibacterial action of curcumin against Staphylococcus aureus: A brief review. J. Trop. Med. 2016, 2016, 2853045. [CrossRef] [PubMed]

13. Farhood, B.; Mortezaee, K.; Goradel, N.H.; Khanlarkhani, N.; Salehi, E.; Nashtaei, M.S.; Najafi, M.; Sahebkar, A. Curcumin as an anti-inflammatory agent: Implications to radiotherapy and chemotherapy. J. Cell. Physiol. 2019, 234, 5728-5740. [CrossRef] [PubMed]

14. Liu, Z.; Huang, P.; Law, S.; Tian, H.; Leung, W.; Xu, C. Preventive effect of curcumin against chemotherapy-induced side-effects Front. Pharmacol. 2018, 9, 1374. [CrossRef]

15. Shanmugam, M.K.; Rane, G.; Kanchi, M.M.; Arfuso, F.; Chinnathambi, A.; Zayed, M.; Alharbi, S.A.; Tan, B.K.; Kumar, A.P.; Sethi, G. The multifaceted role of curcumin in cancer prevention and treatment. Molecules 2015, 20, 2728-2769. [CrossRef]

16. Teiten, M.-H.; Eifes, S.; Dicato, M.; Diederich, M. Curcumin-The paradigm of a multi-target natural compound with applications in cancer prevention and treatment. Toxins 2010, 2, 128-162. [CrossRef] [PubMed]

17. Rahmani, A.H.; Alsahli, M.A.; Aly, S.M.; Khan, M.A.; Aldebasi, Y.H. Role of curcumin in disease prevention and treatment. Adv. Biomed. Res. 2018, 7, 38. [CrossRef] [PubMed]

18. Momtazi-Borojeni, A.A.; Mosafer, J.; Nikfar, B.; Ekhlasi-Hundrieser, M.; Chaichian, S.; Mehdizadehkashi, A.; Vaezi, A. Curcumin in advancing treatment for gynecological cancers with developed drug-and radiotherapy-associated resistance. Rev. Physiol. Biochem. Pharmacol. 2018, 176, 107-129.

19. Tomeh, M.A.; Hadianamrei, R.; Zhao, X. A review of curcumin and its derivatives as anticancer agents. Int. J. Mol. Sci. 2019, 20, 1033. [CrossRef]

20. Kesharwani, S.S.; Ahmad, R.; Bakkari, M.A.; Rajput, M.K.; Dachineni, R.; Valiveti, C.K.; Kapur, S.; Bhat, G.J.; Singh, A.B.; Tummala, H. Site-directed non-covalent polymer-drug complexes for inflammatory bowel disease (IBD): Formulation development, characterization and pharmacological evaluation. J. Control. Release 2018, 290, 165-179. [CrossRef]

21. Kumar, S.; Kesharwani, S.S.; Mathur, H.; Tyagi, M.; Bhat, G.J.; Tummala, H. Molecular complexation of curcumin with pH sensitive cationic copolymer enhances the aqueous solubility, stability and bioavailability of curcumin. Eur. J. Pharm. Sci. 2016, 82, 86-96. [CrossRef]

22. Cheng, Y.; Zhao, P.; Wu, S.; Yang, T.; Chen, Y.; Zhang, X.; He, C.; Zheng, C.; Li, K.; Ma, X. Cisplatin and curcumin co-loaded nano-liposomes for the treatment of hepatocellular carcinoma. Int. J. Pharm. 2018, 545, 261-273. [CrossRef] [PubMed]

23. Ma, L.; Zhang, X.; Wang, Z.; Huang, L.; Meng, F.; Hu, L.; Chen, Y.; Wei, J. Anti-cancer effects of curcumin on myelodysplastic syndrome through the inhibition of enhancer of zeste homolog-2 (EZH2). Curr. Cancer Drug Targets 2019, 19, 729-741. [CrossRef]

24. Tuorkey, M. Curcumin a potent cancer preventive agent: Mechanisms of cancer cell killing. Interv. Med. Appl. Sci. 2014, 6, 139-146. [CrossRef]

25. Fetoni, A.R.; Eramo, S.L.; Paciello, F.; Rolesi, R.; Podda, M.V.; Troiani, D.; Paludetti, G. Curcuma longa (curcumin) decreases in vivo cisplatin-induced ototoxicity through heme oxygenase-1 induction. Otol. Neurotol. 2014, 35, e169-e177. [CrossRef] [PubMed]

26. Salehi, P.; Akinpelu, O.V.; Waissbluth, S.; Peleva, E.; Meehan, B.; Rak, J.; Daniel, S.J. Attenuation of cisplatin ototoxicity by otoprotective effects of nanoencapsulated curcumin and dexamethasone in a guinea pig model. Otol. Neurotol. 2014, 35, 1131-1139. [CrossRef] [PubMed]

27. Zhang, M.; Hagan IV, C.T.; Min, Y.; Foley, H.; Tian, X.; Yang, F.; Mi, Y.; Au, K.M.; Medik, Y.; Roche, K. Nanoparticle co-delivery of wortmannin and cisplatin synergistically enhances chemoradiotherapy and reverses platinum resistance in ovarian cancer models. Biomaterials 2018, 169, 1-10. [CrossRef] [PubMed]

28. Kesharwani, S.S.; Kaur, S.; Tummala, H.; Sangamwar, A.T. Overcoming multiple drug resistance in cancer using polymeric micelles. Expert Opin. Drug Deliv. 2018, 15, 1127-1142. [CrossRef] [PubMed]

29. Choi, J.H.; Joung, Y.K.; Bae, J.W.; Choi, J.W.; Quyen, T.N.; Park, K.D. Self-assembled nanogel of pluronic-conjugated heparin as a versatile drug nanocarrier. Macromol. Res. 2011, 19, 180-188. [CrossRef] 
30. Tong, N.-A.N.; Tran, N.Q.; Nguyen, X.T.D.T.; Cao, V.D.; Nguyen, T.P.; Nguyen, C.K. Thermosensitive heparin-Pluronic ${ }^{\circledR}$ copolymer as effective dual anticancer drugs delivery system for combination cancer therapy. Int. J. Nanotechnol. 2018, 15, 174-187. [CrossRef]

31. Nguyen, D.T.; Dinh, V.T.; Dang, L.H.; Nguyen, D.N.; Giang, B.L.; Nguyen, C.T.; Nguyen, T.B.T.; Thu, L.V.; Tran, N.Q. Dual interactions of amphiphilic gelatin copolymer and nanocurcumin improving the delivery efficiency of the nanogels. Polymers 2019, 11, 814. [CrossRef]

32. Chiappetta, D.A.; Sosnik, A. Poly (ethylene oxide)-poly (propylene oxide) block copolymer micelles as drug delivery agents: Improved hydrosolubility, stability and bioavailability of drugs. Eur. J. Pharm. Biopharm. 2007, 66, 303-317. [CrossRef] [PubMed]

33. Van Thoai, D.; Nguyen, D.T.; Dang, L.H.; Nguyen, N.H.; Nguyen, V.T.; Doan, P.; Nguyen, B.T.; Tung, N.N.; Quyen, T.N. Lipophilic effect of various pluronic-grafted gelatin copolymers on the quercetin delivery efficiency in these self-assembly nanogels. J. Polym. Res. 2020, 27, 369. [CrossRef]

34. Tong, N.-A.N.; Nguyen, T.P.; Cuu Khoa, N.; Tran, N.Q. Aquated cisplatin and heparin-pluronic nanocomplexes exhibiting sustainable release of active platinum compound and NCI-H460 lung cancer cell antiproliferation. J. Biomater. Sci. Polym. Ed. 2016, 27, 709-720. [CrossRef] [PubMed]

35. Dehvari, K.; Lin, K.-S.; Hammouda, B. Small-angle neutron scattering studies of microenvironmental and structural changes of Pluronic micelles upon encapsulation of paclitaxel. J. Taiwan Inst. Chem. Eng. 2017, 71, 405-413. [CrossRef]

36. Kabanov, A.V.; Batrakova, E.V.; Alakhov, V.Y. Pluronic ${ }^{\circledR}$ block copolymers for overcoming drug resistance in cancer. Adv. Drug Deliv. Rev. 2002, 54, 759-779. [CrossRef]

37. Nasir, N.; Ahmad, M.; Minhas, M.U.; Barkat, K.; Khalid, M.F. pH-responsive smart gels of block copolymer [pluronic F127-co-poly (acrylic acid)] for controlled delivery of Ivabradine hydrochloride: Its toxicological evaluation. J. Polym. Res. 2019, 26, 212. [CrossRef]

38. Hamzah, Y.B.; Hashim, S.; Abd Rahman, W.A.W. Synthesis of polymeric nano/microgels: A review. J. Polym. Res. 2017, 24, 134. [CrossRef]

39. Dang, L.H.; Nguyen, T.H.; Tran, H.L.B.; Doan, V.N.; Tran, N.Q. Injectable nanocurcumin-formulated chitosan-g-pluronic hydrogel exhibiting a great potential for burn treatment. J. Healthc. Eng. 2018, 2018, 5754890. [CrossRef]

40. Nguyen, T.T.C.; Nguyen, C.K.; Nguyen, T.H.; Tran, N.Q. Highly lipophilic pluronics-conjugated polyamidoamine dendrimer nanocarriers as potential delivery system for hydrophobic drugs. Mater. Sci. Eng. C 2017, 70, 992-999. [CrossRef]

41. Liang, Y.; Kiick, K.L. Heparin-functionalized polymeric biomaterials in tissue engineering and drug delivery applications. Acta Biomater. 2014, 10, 1588-1600. [CrossRef] [PubMed]

42. Glimelius, B.; Busch, C.; Höök, M. Binding of heparin on the surface of cultured human endothelial cells. Thromb. Res. 1978, 12, 773-782. [CrossRef]

43. Shing, Y.; Folkman, J.; Sullivan, R.; Butterfield, C.; Murray, J.; Klagsbrun, M. Heparin affinity: Purification of a tumor-derived capillary endothelial cell growth factor. Science 1984, 223, 1296-1299. [CrossRef] [PubMed]

44. Ding, H.; Yong, K.-T.; Law, W.-C.; Roy, I.; Hu, R.; Wu, F.; Zhao, W.; Huang, K.; Erogbogbo, F.; Bergey, E.J. Non-invasive tumor detection in small animals using novel functional Pluronic nanomicelles conjugated with anti-mesothelin antibody. Nanoscale 2011, 3, 1813-1822. [CrossRef] [PubMed]

45. Pham, L.; Truong, M.D.; Nguyen, T.H.; Le, L.; Nam, N.D.; Bach, L.G.; Nguyen, V.T.; Tran, N.Q. A dual synergistic of curcumin and gelatin on thermal-responsive hydrogel based on Chitosan-P123 in wound healing application. Biomed. Pharmacother. 2019, 117, 109183. [CrossRef]

46. Zhu, Y.; Noy, J.-M.; Lowe, A.B.; Roth, P.J. The synthesis and aqueous solution properties of sulfobutylbetaine (co) polymers: Comparison of synthetic routes and tuneable upper critical solution temperatures. Polym. Chem. 2015, 6, 5705-5718. [CrossRef]

47. Mahou, R.; Wandrey, C. Versatile route to synthesize heterobifunctional poly (ethylene glycol) of variable functionality for subsequent pegylation. Polymers 2012, 4, 561-589. [CrossRef]

48. Mulloy, B.; Forster, M.; Jones, C.; Davies, D. Nmr and molecular-modelling studies of the solution conformation of heparin. Biochem. J. 1993, 293, 849-858. [CrossRef]

49. Fares, A.R.; ElMeshad, A.N.; Kassem, M.A. Enhancement of dissolution and oral bioavailability of lacidipine via pluronic P123/F127 mixed polymeric micelles: Formulation, optimization using central composite design and in vivo bioavailability study. Drug Deliv. 2018, 25, 132-142. [CrossRef] [PubMed]

50. Nguyen, T.D.; Nguyen, T.T.T.; Ivanov, I.A.; Nguyen, K.C.; Tran, Q.N.; Hoang, A.N.; Utkin, Y.N. Nanoencapsulation enhances anticoagulant activity of adenosine and dipeptide IleTrp. Nanomaterials 2019, 9, 1191. [CrossRef]

51. Wang, X.; Gao, Y.; Wang, W.; Qin, A.; Sun, J.Z.; Tang, B.Z. Different amine-functionalized poly (diphenylsubstituted acetylenes) from the same precursor. Polym. Chem. 2016, 7, 5312-5321. [CrossRef]

52. Martins, A.F.; Pereira, A.G.; Fajardo, A.R.; Rubira, A.F.; Muniz, E.C. Characterization of polyelectrolytes complexes based on N, N, N-trimethyl chitosan/heparin prepared at different pH conditions. Carbohydr. Polym. 2011, 86, 1266-1272. [CrossRef]

53. Peng, J.; Qi, T.; Liao, J.; Chu, B.; Yang, Q.; Li, W.; Qu, Y.; Luo, F.; Qian, Z. Controlled release of cisplatin from pH-thermal dual responsive nanogels. Biomaterials 2013, 34, 8726-8740. [CrossRef] [PubMed]

54. Zhuang, W.; Ma, B.; Liu, G.; Chen, X.; Wang, Y. A fully absorbable biomimetic polymeric micelle loaded with cisplatin as drug carrier for cancer therapy. Regen. Biomater. 2018, 5, 1-8. [CrossRef] [PubMed] 
55. Trummer, R.; Rangsimawong, W.; Sajomsang, W.; Kumpugdee-Vollrath, M.; Opanasopit, P.; Tonglairoum, P. Chitosan-based self-assembled nanocarriers coordinated to cisplatin for cancer treatment. RSC Adv. 2018, 8, 22967-22973. [CrossRef]

56. Kirkpatrick, G.J.; Plumb, J.A.; Sutcliffe, O.B.; Flint, D.J.; Wheate, N.J. Evaluation of anionic half generation 3.5-6.5 poly (amidoamine) dendrimers as delivery vehicles for the active component of the anticancer drug cisplatin. J. Inorg. Biochem. 2011, 105, 1115-1122. [CrossRef] [PubMed]

57. Mircioiu, C.; Voicu, V.; Anuta, V.; Tudose, A.; Celia, C.; Paolino, D.; Fresta, M.; Sandulovici, R.; Mircioiu, I. Mathematical modeling of release kinetics from supramolecular drug delivery systems. Pharmaceutics 2019, 11, 140. [CrossRef]

58. Shaikh, H.K.; Kshirsagar, R.; Patil, S. Mathematical models for drug release characterization: A review. World J. Pharm. Pharm. Sci. 2015, 4, 324-338.

59. Pawar, A.; Singh, S.; Rajalakshmi, S.; Shaikh, K.; Bothiraja, C. Development of fisetin-loaded folate functionalized pluronic micelles for breast cancer targeting. Artif. Cells Nanomed. Biotechnol. 2018, 46, 347-361. [CrossRef]

60. Kuksal, A.; Tiwary, A.K.; Jain, N.K.; Jain, S. Formulation and in vitro, in vivo evaluation of extended-release matrix tablet of zidovudine: Influence of combination of hydrophilic and hydrophobic matrix formers. AAPS Pharmscitech 2006, 7, E1-E9. [CrossRef]

61. Sahu, A.; Kasoju, N.; Goswami, P.; Bora, U. Encapsulation of curcumin in Pluronic block copolymer micelles for drug delivery applications. J. Biomater. Appl. 2011, 25, 619-639. [CrossRef] [PubMed]

62. Nguyen, M.-N.T.; Ho-Huynh, T.-D. Selective cytotoxicity of a Vietnamese traditional formula, Nam Dia long, against MCF-7 cells by synergistic effects. BMC Complement. Altern. Med. 2016, 16, 220. [CrossRef] [PubMed] 